\title{
Islah Amaçlı Yetiştirici Birlikleri ile Üyeleri Arasındaki İlişkilerin Analizi: Sivas İli Örneği
}

\author{
Murat DEMİRBÜK ${ }^{1}$, Nuray KIZILASLAN ${ }^{2}$ \\ ${ }^{1}$ United Nations Development Programme, Göksu Taşeli Havzası Kalkınma Projesi, Karaman, ${ }^{2}$ Gaziosmanpaşa Üniversitesi, \\ Ziraat Fakültesi, Tarım Ekonomisi Bölümü, Tokat-Türkiye \\ ${ }^{1}$ https://orcid.org/0000-0001-5535-1949, ${ }^{2}$ https://orcid.org/0000-0002-8535-0100 \\ $\varangle$ :mdemirbuk@hotmail.com
}

\section{ÖZET}

Çiftçi örgütlenmesi, bireysel çiftçilerin değişen pazar koşullarına uyum sağlayabilmeleri için önemlidir. Küçük ve orta ölçekli çiftçiler varlıklarını sürdürebilmek için örgütlenmelidir. Kalkınmakta olan ülkelerde örgütlenme düzeyi istenilen seviyenin altındadır. Çalışma yetiştiricilerin sosyo-ekonomik durumlarını, problemlerini, birlikleri ile olan ilişkilerini araştırmaktadır ve Sivas ilinde örgütlü bulunan üç birliğini kapsamaktadır. Bunlar; Damızlık Sığır, Damızlık Koyun Keçi ve Arı yetiştiricileri birlikleridir. 94 sığır yetiştiricisi, 168 koyun ve keçi yetiştiricisi, 107 arı yetiştiricisi olmak üzere toplam 369 anket yapılmıştır. Verilerin analizinde Ki-kare, Kruskal-Wallis ve MannWhitney U testleri kullanılmıştır. Farklı birliklerin üyelerinin gelir, pazarlama, genel kurullara katılım, eğitim ve bilgi kaynakları ile üyelik aşamasında ikna edici faktörler açısından istatistiksel olarak farklılaştığ birliklerin görev ve sorumluluklarını bilmediklerini beyan etmişlerdir. Kamunun, birliklerin ve çiftçilerin daha etkin çiftçi örgütlenmesi için birlikte çalışmaları gerekmektedir. Birliklerin girdi temini, tarımsal yayım ve pazarlama konularında daha çok çalışmalıdır. Tüm aktiviteleri üyelerin uygun olduğu zamanlarda, günlük ve mevsimsel tarım takvimine göre düzenlemelidirler.

\section{Araștırma Makalesi}

\section{Makale Tarihçesi}

Geliş Tarihi : 10.05 .2019

Kabul Tarihi : 11.09 .2019

\section{Anahtar Kelimeler}

Üretici birlikleri

Çiftçi

Üye

Örgütlenme

Sivas

\section{Analysis of Relationships between Breeders' Associations and Their, A Case Study of Sivas}

\section{ABSTRACT}

Farmers' organization is important for individual farmers to adapt changing market conditions. Small and medium size farmers have to be organized in order to survive. In developing countries, organization is below the desired level. This research aimed to identify breeders' socio-economic status, problem and relations with associations. The study covered three Breeders Association in Sivas. These were Cattle, Sheep and Goat Breeders' Association and Associations of Beekeepers. A survey was conducted with total of 369,94 cattle breeders, 168 sheep and goat breeders and 107 beekeepers. Chi square, Kruskal-Wallis and Mann-Whitney $U$ tests were used to analyze the data. It was determined that member of different associations differed statistically in terms of income, marketing, participation in general assemblies, training and basic information sources, convincing factor to become a member. It was found that $27.5 \%$ of the respondents did not know associates' task and responsibilities. Government, unions and farmers must work jointly and each side take some actions for more effective farmer organization. It can be suggested that the associations have to do much more serious and intensive work on the subject of providing input, agricultural extension and marketing organizations for members. All activities have to be designed based on member's availability, daily and seasonal agricultural calendar.

\section{Research Article}

$\begin{array}{ll}\text { Article History } & \\ \text { Received } & : 10.05 .2019 \\ \text { Accepted } & : 11.09 .2019\end{array}$

Keywords
Breeders' association
Farmer
Member
Organization
Sivas

To Cite : Demirbük M, Kızılaslan N 2020. Islah Amaçlı Yetiştirici Birlikleri ile Üyeleri Arasındaki İlişkilerin Analizi: Sivas İli Örneği. KSÜ Tarım ve Doğa Derg 23 (1): 194-211. DOI: 10.18016/ ksutarimdoga.vi.562087. 


\section{GİRIŞ}

Çiftçi örgütlenmesi, bireysel çiftçilerin tarım sektöründeki büyük firmalarla rekabet edebilmeleri ve değişen pazar koşullarına uyum sağlayabilmeleri için önemli bir araçtır. Küçük ve orta ölçekli çiftçiler varlıklarını sürdürebilmek ve gelirlerini artırabilmek için örgütlenmek zorundadırlar. Özellikle kalkınmakta olan ülkelerde örgütlenme düzeyi istenilen seviyenin altındadır. Türkiye'de üreticilerin mevcut örgütlere katılımı veya ihtiyaçları doğrultusunda yeni örgütlenmeler oluşturmaları çeşitli nedenlerle istenilen hızda ilerlememekte ve çeşitli faktörler tarafindan etkilenmektedir. Bu faktörlerin bir kısmı yasal düzenlemelerden kaynaklanırken önemli bir bölümü de mevcut örgütlerin görev ve sorumluluğunu yerine getirmemesi, üyelerin bu örgütler üzerinde etkin olamaması gibi nedenlerden kaynaklanmaktadır.

Üreticilerin etkili bir biçimde örgütlenmesi tarımsal üretimi arttırmanın, kaliteli ürün elde etmenin ve tarım ile uğraşanların yaşam düzeylerini yükseltmenin en önemli yollarından biridir. Gelişmiş ülkelere bakıldığında, tarımsal kalkınmanın gerçekleştiği ve üretici örgütlerinin de güçlü bir şekilde var olduğu görülmektedir. Tarım politikalarının oluşturulması, uygulama koşullarının belirlenmesi ve böylece politik mekanizmaları etkileyebilmek, pazarda etkin olabilmek, çağdaş üretim yöntemlerini kullanıp verimliliği arttırarak kırsal alan kalkınmasını gerçekleştirmek ancak örgütlenmeden gelen güçle olasıdır (İnan ve ark., 2000).

Gelişmiş ülkelerdeki etkin çiftçi örgütleri demokratik birer baskı unsurları olarak çiftçilerin seslerinin duyurulması ve üretim etkinliğini artırmak için eğitim ve yayım faaliyetlerinde de bulunmaktadirlar. Kalkınmakta olan ülkelerde ise örgütlenmenin ya hiç oluşmadığı ya da etkin olmadığı, teorik olarak çiftçi kuruluşları olmakla birlikte, daha çok devlet kuruluşları gibi çalıştıkları görülmektedir. Ancak özellikle kalkınmakta olan ülkelerde çiftçi örgütlerinin kurulması ve etkin hale getirilmesi büyük önem taşımaktadır (Çetin, 2013).

Bir üretici örgütlenmesi, işlevlerine ve amaçlarına dayanılarak tanımlanır. Önemli olan tarım üreticilerinin kendi inisiyatiflerine dayanılarak kurulmuş olmaları ve öncelikle üretim ve satışları pazar ihtiyaçlarına uyarlayarak üye çiftliklerin ekonomik etkinliklerinin geliştirilmesi amacını taşımalarıdır. Bu nedenle üretici örgütlenmesi terimi herhangi bir yasal formu işaret etmemekle birlikte ana amacı üye üreticilerin ürünlerine pazarda yer açmak olan organizasyonu tarif ettiği söylenebilir. Literatürde ekonomik ve teknik anlamda hizmet sağlayan üretici örgütleri farklı adlarla anılmaktadır. Tüm bu farklı organizasyonların ortak paydası üyelerinin refah düzeyini artırmaktır. İlave olarak üyelerin sahip olduğu üretici örgütleri, kendilerine özgü fayda sağlayacak şekilde üyeler tarafından kurulur, denetlenir ve yönetilir (Falkowski ve Ciaian, 2016).

Bu çalışma 5996 Sayılı Kanununa dayanarak Sivas ilinde örgütlenmiş, Damızlık Sığır Yetiştiricileri Birliği (DSYB), Damızlık Koyun Keçi Yetiştiricileri Birliği (DKKYB) ve Arı Yetiştiricileri Birliği (AYB) temel alınarak yapılmıştır. Bu çalışma, yetiştiricilerin sosyo ekonomik durumlarının, yetiştirici birlikleri ile üyeler arasındaki ilişkilerinin analizi ile mevcut durumun ortay konulması sonucu daha etkin bir örgütlenme için yapılabilecekler konusunda öneriler geliştirmek amacıyla yapılmıştır.

\section{MATERYAL ve YÖNTEM}

Çalışmanın ana verileri Sivas'ta örgütlü bulunan yetiştirici birliklerinin üyelerinden yüz yüze anket yolu ile elde edilen bilgilerden oluşmaktadır. Örneklem sayısının tespitinde, ana kütlenin varyansı ve ana kütledeki birim sayısı bilindiği için;

$n=\frac{\mathrm{N} *(\mathrm{Z} \alpha / 2)^{2} * \sigma^{2}}{(\mathrm{~N}-1) \mathrm{d}^{2}+\left(\frac{\mathrm{Z} \alpha}{2}\right)^{2} * \sigma^{2}}$ Formülü kullanılmıştır (Yamane, 2006)

$\mathrm{n}=$ Örneklem hacmi

$\mathrm{N}=$ Ana kütledeki birim sayısını

$\mathrm{Z}$ a 2= Standart normal dağılım değerini

$\sigma^{2}=$ Ana kütlenin varyansını

$\mathrm{d}=$ Ana kütle ortalaması ile örneklem ortalaması arasındaki sapma miktarını göstermektedir.

\% 95 güven aralığında $\mathrm{z}=1.96$ olarak alınarak, değerler formülde yerlerine konulmuş, yapılan hesaplama sonucu örneklem hacmi, DSYB için 94, DKKYB için 168 ve AYB için ise 107 olarak bulunmuştur.

Ana kütlenin dağılımının bilinmediği veya normal dağılım koşulunun yerine gelmediği durumlarda parametrik olmayan hipotez testi yöntemleri kullanılmaktadır. Parametrik olmayan testler çok fazla koşul gerektirmediği için kullanım alanları oldukça geniştir (Göktolga, 2015).

Verilerin normal dağılıma sahip olup olmadıklarını görebilmek için Kolmogorov-Smirnov ve Shapiro-Wilk testleri kullanılmıştır. Verilerin normal dağılım göstermediği tespit edildikten sonra parametrik olmayan testlerin kullanılmasına karar verilmiştir. Khi kare, Kruskal-Wallis ve Mann-Whitney U testleri kullanılarak veriler analiz edilmiştir.

\section{BULGULAR ve TARTIŞMA}

Çalışma alanında örgütlü bulunan DSYB, DKKYB ve AYB'ye üye yetiştiricilere ait sosyo-ekonomik özellikler analiz edilmiş ve bulunan sonuçlar yorumlanmıştır. Yetiştiricilerin eğitim durumlarını 
gösterir Çizelge 1'e bakıldığında \% 66'sı ilköğretim mezunu olarak görülmektedir. Hiç eğitimi olmayanların oranı \% 3.5’tir, üniversite mezunlarının oranı ise \% 6.5'tir. Bilginturan ve Ayhan'ın (2009), Burdur İlinde yaptıkları çalışmada, koyun yetiştiricilerinin \% 90,3’ünün ilkokul, \% 7.7'sinin lise, \% 0.5’inin yüksekokul mezunu olduğu görülürken \% 1.5’inin ise okuryazar olmadığı görülmektedir. Eğitimi olmayanların oranı Sivas'taki çalışmada daha yüksek bulunmuş buna karşın lise ve yüksekokul mezunu olan koyun yetiştiricilerinin oranı da Sivas'ta yüksek çıkmıştır.

Ege ve Orta Anadolu Bölgesindeki DSYB üyesi süt sığırcılık işletmelerine yönelik yapılan çalışmada işletme sahiplerinin \% 0.9 'unun okuma yazma bilmediği \% 11.4'ünün okuryazar, \% 63’ünün ilköğretim, \% 20.9'unun lise, \% 1.6‘sının da lisans düzeyinde mezun olduğu tespit edilmiştir (Murat, 2011). Edirne'de yapılan çalışmada, işletme sahiplerinin \% 75.4'ü ilkokul mezunu, \% 21.1'i ortaokul mezunu, \% 3.5'i lise mezunu olup yüksekokul mezunu bulunmadığı belirlenmiştir (Önal ve Özder, 2008). Samsun'da yapılan çalışmada, üretici örgütüne üye olanlardan, eğitim durumu okuryazar olmayan, ilkokul ve ortaokul mezunlarmın toplamı \% 91.3’ü bulmaktadır (Aydoğan ve Yulafçı, 2014). Uşak ilinde tarımsal üretici örgütleri üyelerine yönelik yapılan çalışmada ise ilköğretim mezunu \% 55.3, orta öğretim mezunu \% 38.3 ve yükseköğretim mezunu \% 6.4'tür (Sağlam, 2013). Edirne DSYB üyeleri ile ilgili yapılan çalışmada işletme sahiplerinin \% 70'i lise, \% 19'u ortaokul, \% 7'si ilkokul ve \% 4'ü yüksekokul mezunudur (Karaturhan ve ark., 2014).

Çizelge 1. Birliklere üye yetiştiricilerin eğitim durumu

Table 1. Educational status of member of associations

\begin{tabular}{|c|c|c|c|c|c|c|}
\hline \multirow{2}{*}{\multicolumn{2}{|c|}{$\begin{array}{l}\text { Yetiştirici Birlikleri } \\
\text { Breeder Associations }\end{array}$}} & \multicolumn{4}{|c|}{ Eğitim Durumu (Education Status) } & \multirow[b]{2}{*}{$\begin{array}{c}\text { Toplam } \\
\text { Total }\end{array}$} \\
\hline & & $\begin{array}{c}\text { Ĕ̈itim yok } \\
\text { No education }\end{array}$ & $\begin{array}{c}\text { İlköğretim } \\
\text { Primary education }\end{array}$ & $\begin{array}{c}\text { Lise } \\
\text { High school }\end{array}$ & $\begin{array}{l}\text { Üniversite } \\
\text { University }\end{array}$ & \\
\hline \multirow{4}{*}{ DSYB } & Sayı (Count) & 1 & 71 & 21 & 1 & 94 \\
\hline & $\begin{array}{l}\text { Birlik içindeki \% (Within } \\
\text { associations) }\end{array}$ & 1.1 & 75.5 & 22.3 & 1.1 & 100.0 \\
\hline & $\begin{array}{l}\text { Grup içindeki \% (Within } \\
\text { group) }\end{array}$ & 7.7 & 29.1 & 23.9 & 4.2 & 25.5 \\
\hline & Genel \% (General) & 0.3 & 19.2 & 5.7 & 0.3 & 25.5 \\
\hline \multirow{4}{*}{ DKKYB } & Sayı (Count) & 9 & 122 & 32 & 5 & 168 \\
\hline & $\begin{array}{l}\text { Birlik içindeki \% (Within } \\
\text { associations) }\end{array}$ & 5.4 & 72.6 & 19.0 & 3.0 & 100.0 \\
\hline & $\begin{array}{l}\text { Grup içindeki \% (Within } \\
\text { group) }\end{array}$ & 69.2 & 50.0 & 36.4 & 20.8 & 45.5 \\
\hline & Genel \% (General) & 2.4 & 33.1 & 8.7 & 1.4 & 45.5 \\
\hline \multirow{4}{*}{ AYB } & Sayı (Count) & 3 & 51 & 35 & 18 & 107 \\
\hline & $\begin{array}{l}\text { Birlik içindeki \% (Within } \\
\text { associations) }\end{array}$ & 2.8 & 47.7 & 32.7 & 16.8 & 100.0 \\
\hline & $\begin{array}{l}\text { Grup içindeki \% Within } \\
\text { group }\end{array}$ & 23.1 & 20.9 & 39.8 & 75.0 & 29.0 \\
\hline & Genel \% (General) & 0.8 & 13.8 & 9.5 & 4.9 & 29.0 \\
\hline \multirow{2}{*}{$\begin{array}{l}\text { Genel } \\
\text { General }\end{array}$} & Sayı (Count) & 13 & 244 & 88 & 24 & 369 \\
\hline & Toplam \% (Total) & 3.5 & 66.1 & 23.8 & 6.5 & 100.0 \\
\hline
\end{tabular}

Yetiştiricilerin yaş gruplarına göre dağılımlarına bakıldığında 40-60 yaş arası grup \% 60'a yakın bir oranı oluşturmaktadır. Çalışma bölgesindeki yetiştiricilerin yaş ortalaması 49.3 olarak bulunmuştur.

Samsun'da yapılan çalışmada üreticilerin ortalama yaşları 51.5 olarak tespit edilmiştir (Aydoğan ve Yulafçı, 2014). Van'da yapılan bir çalışmada tarımsal üretici örgütüne üye olan üreticilerin \% 12.2'sinin 22 $30, \%$ 15.3'ünün $31-40, \% 37.8$ 'inin $40-50$ ve \% 34.7'sinin 51 ve üzeri yaş grubunda oldukları belirlenmiştir (Terin ve Ateş, 2010). Sivas'ta 50 yaş üzeri yetiştiricilerin oranı $\% 51$ olarak bulunmuştur.

Yine Uşak'ta yapılan çalışmada 20-30 yaş grubunda \% $11.9,31-40$ yaş grubunda \% 26.1, 41-50 yaş grubunda $\% 31.1,51-60$ yaş grubunda \% 20.8 ve 61 yaş ve üzeri yaş grubunda oran ise $\% 10$ dur. Uşak'ta 30 ile 50 yaş arası grup \% 57.2 iken Sivas'ta \% 44.1'dir (Sağlam, 2013).

Yetiştiricilerin yaklaşık \% 5’i sosyal güvenlikten mahrumdur. Sosyal güvenliği olmayanların çok büyük bir çoğunluğu (\% 78.9) DKKYB üyesidir. Emekli 
sandığına bağlı olanların ise \% 77.1'i AYB üyesidir. Yetiştiricilerin yarısından fazlası (\%54.5) BağKurludur. SSK ve Emekli sandiğına kayıtlı olduğunu belirten \%40'ın üzerindeki yetiştiricinin başka bir gelir kaynağına sahip olduğu söylenebilir. Arıcılık faaliyetinin kamu çalışanları tarafından da yapilabilecek ek bir faaliyettir. $\mathrm{Bu}$ nedenle AYB üyelerinin emekli sandığı üyelik oranları diğer faaliyet alanlarındaki yetiştiricilere göre daha yüksek çıkmaktadır.

Gelir açısından bakıldığında, DKKYB üyelerinin düzeltilmiş ortalama geliri diğer birlik üyelerinden yüksektir. Çizelge 2'de görülebileceği gibi en düşük gelir ise AYB üyelerine aittir. AYB üyelerinin önemli bir kısmı arıcılık faaliyetini ek gelir getirici bir faaliyet olarak ve birincil işlerini aksatmamaya çalışarak yapmaktadır.

Çizelge 2. Birliklere göre üyelerin faaliyet geliri (TL YIL)

Table 2. Operating income of the members by associations (TL YEAR)

\begin{tabular}{|c|c|c|}
\hline \multirow[b]{2}{*}{ DSYB } & Ortalama (Average) & 79.191 \\
\hline & $\begin{array}{l}\% 5 \text { Düzeltilmiş ortalama } \\
\text { Adjusted average of } 5 \%\end{array}$ & 57.413 \\
\hline \multirow[b]{2}{*}{ DKKYB } & Ortalama (Average) & 69.220 \\
\hline & $\begin{array}{l}\% 5 \text { Düzeltilmiş ortalama } \\
\text { Adjusted average of } 5 \%\end{array}$ & 66.031 \\
\hline \multirow[b]{2}{*}{ AYB } & Ortalama (Average) & 57.579 \\
\hline & $\begin{array}{l}\% 5 \text { Düzeltilmiş ortalama } \\
\text { Adjusted average of } 5 \%\end{array}$ & 45.578 \\
\hline
\end{tabular}

Farklı birliklerin üyeleri arasında faaliyet gelirleri açısından istatistiksel olarak anlamlı bir farklılık olduğu görülmüştür. Farklılığın kaynağını tespit edebilmek için ikili gruplar halinde birliklere MannWhitney U testi uygulanmış ve sonuçlar Çizelge 3'te verilmiştir. Tüm gruplar açısından istatistiksel olarak $\% 5$ düzeyinde bir fark vardır ancak en büyük fark DKKYB ile AYB üyeleri arasındadır. Parametrik olmayan testlerin kullanımının doğruluğu Çizelge 4'te verilen normallik testi sonuçlarından sağlanmıştır.

Yetiştiricilerin mesleki deneyim durumları ve 49.3 olan yaş ortalamaları birlikte değerlendirildiğinde son yıllarda çalışma kapsamına giren yetiştiricilik faaliyetlerine gençlerin ilgi göstermediği söylenebilir. 5 yıldan daha az mesleki deneyimi olanların oranı \% 7.6'dır. Samsun'da yapılan çalışmada tarımsal üretici örgütüne üye olan üreticilerin ortalama tarımsal deneyimi 22.6 yıl bulunmuştur (Aydoğan ve Yulafçı, 2014). Van'da ise üreticilerin \% 71.2'sinin 21 yll ve üzeri deneyime sahip olduğu ve ortalama deneyim süresinin 30 yıl olduğu saptanmıştır (Terin ve Ateş, 2010).

Yetiştiricilerin ürünlerini pazarlama kanallarına ilişkin veriler Çizelge 5’te verilmiştir. Birlik aracılığı ile ürünlerini pazarlayanlarm \% 77.5'i DSYB üyeleridir. Bu oran DKKYB' inde \%17.5, AYB de ise sadece \% 5'tir. DSYB'nin araştırma bölgesinde bir süt toplama organizasyonunun olması ürünlerin birlik aracılığı ile pazarlanması üzerinde oldukça etkilidir denebilir. Ancak AYB üyelerinin \% 92.5'i, DSYB üyelerinin \% 62.8'i ve DKKYB üyelerinin ise \%60.7'si ürünlerini kendi olanakları ile pazarladığını bildirmiştir. Pazarlama ile ilgili durum Çizelge 5’te verilmiştir.

Genel olarak birliklerin pazarlama organizasyonları konusunda yetersiz kaldığı söylenebilir. Toplamda yetiştiricilerin \% 18.7'si ürünlerini aracılara, toptancılara verdiğini belirtmiştir ve bu grubun içerisinde DKKYB üyelerinin oranı \% 85.5'tir.

Samsunda yapılan çalışmada üyesi olduğunuz tarımsal üretici örgütü ürünlerinize pazar bulma çalışması yapıyor mu sorusuna üyelerin \% 44.2'si evet, $\% 55.8$ 'i ise hayır yanıtını vermiştir.

Çizelge 3. Faaliyet gelirlerinin farklılık kaynağı Mann-Whitney U testi tablosu

Table 3. Operating income source of their differences, Mann-Whitney U-test table

\begin{tabular}{|c|c|c|c|c|c|c|c|c|}
\hline \multirow{2}{*}{$\begin{array}{l}\text { Gelir } \\
\text { (Income) }\end{array}$} & \multirow{2}{*}{$\begin{array}{l}\text { Birlik } \\
\text { Associations }\end{array}$} & \multirow{2}{*}{$\mathrm{N}$} & \multicolumn{2}{|c|}{ Sıra Sayıları (Ordinal numbers) } & \multirow{2}{*}{$\begin{array}{c}\text { Mann- } \\
\text { Whitney U }\end{array}$} & \multirow{2}{*}{$\begin{array}{l}\text { Wilcoxon } \\
\text { W }\end{array}$} & \multirow{2}{*}{$\mathrm{Z}$} & \multirow{2}{*}{$\mathrm{P}$} \\
\hline & & & Ortalama (Average) & Toplam (Total) & & & & \\
\hline \multirow{2}{*}{ Grup 1} & DSYB & 94 & 118.68 & 11155.50 & \multirow[t]{2}{*}{6690.500} & \multirow[t]{2}{*}{11155.500} & \multirow[t]{2}{*}{-2.052} & \multirow[t]{2}{*}{.040} \\
\hline & DKKYB & 168 & 138.68 & 23297.50 & & & & \\
\hline \multirow{2}{*}{ Grup 2} & DSYB & 94 & 109.84 & 10324.50 & \multirow[t]{2}{*}{4198.500} & \multirow[t]{2}{*}{9976.500} & \multirow[t]{2}{*}{-2.025} & \multirow[t]{2}{*}{.043} \\
\hline & AYB & 107 & 93.24 & 9976.50 & & & & \\
\hline \multirow{2}{*}{ Grup 3} & DKKYB & 168 & 155.02 & 26043.00 & \multirow[t]{2}{*}{6129.000} & \multirow[t]{2}{*}{11907.000} & \multirow[t]{2}{*}{-4.454} & \multirow[t]{2}{*}{.000} \\
\hline & AYB & 107 & 111.28 & 11907.00 & & & & \\
\hline
\end{tabular}

Çizelge 4. Veriler için normallik testi

Table 4. Normality test for data

\begin{tabular}{|l|c|c|c|c|c|c|}
\hline & \multicolumn{3}{|c|}{ Kolmogorov-Smirnov } & \multicolumn{3}{c|}{ Shapiro-Wilk } \\
\cline { 2 - 7 } & $\begin{array}{l}\text { İstatistik } \\
\text { Statistics }\end{array}$ & $\begin{array}{c}\mathrm{Sd} \\
d f\end{array}$ & $\mathrm{p}$ & $\begin{array}{c}\text { İstatistik } \\
\text { Statistics }\end{array}$ & $\begin{array}{c}\mathrm{Sd} \\
d f\end{array}$ & $\mathrm{p}$ \\
\hline Temel gelir (Basic income) & .250 & 369 & .000 & .779 & 369 & .000 \\
\hline Faaliyet geliri (Operatin income) & .325 & 369 & .000 & .302 & 369 & .000 \\
\hline
\end{tabular}


Çizelge 5. Yetiştiricilerin ürünleri pazarlama durumu

Table 5. Breeders' marketing status of products

\begin{tabular}{|c|c|c|c|c|c|}
\hline \multirow{2}{*}{\multicolumn{2}{|c|}{$\begin{array}{l}\text { Ürün Pazarlama Durumu } \\
\text { Marketing Sstatus of Products }\end{array}$}} & \multicolumn{3}{|c|}{$\begin{array}{l}\text { Yetiştirici Birlikleri } \\
\text { Breeder Associations }\end{array}$} & \multirow{3}{*}{$\begin{array}{c}\text { TOPLAM } \\
\text { TOTAL } \\
40 \\
\end{array}$} \\
\hline & & \multirow{2}{*}{$\begin{array}{c}\text { DSYB } \\
31\end{array}$} & \multirow{2}{*}{$\frac{\text { DKKYB }}{7}$} & \multirow{2}{*}{ AYB } & \\
\hline \multirow{3}{*}{$\begin{array}{l}\text { Birlik aracılığ ile } \\
\text { Through the Associations }\end{array}$} & Sayı (Count) & & & & \\
\hline & Grup içindeki \% (\% within group) & 77.5 & 17.5 & 5.0 & 100.0 \\
\hline & Birlik içindeki \% (\% within association) & 33.0 & 4.2 & 1.9 & 10.8 \\
\hline \multirow{3}{*}{$\begin{array}{l}\text { Kendi olanaklarim ile } \\
\text { With my own facilities }\end{array}$} & Sayı $($ Count $)$ & 59 & 102 & 99 & 260 \\
\hline & Grup içindeki \% (\% within group) & 22.7 & 39.2 & 38.1 & 100.0 \\
\hline & Birlik içindeki \% (\% within association) & 62.8 & 60.7 & 92.5 & 70.5 \\
\hline \multirow{3}{*}{$\begin{array}{l}\text { Aracilara/Toptancilara } \\
\text { Middleman/Wholesaler }\end{array}$} & Sayı $($ Count $)$ & 4 & 59 & 6 & 69 \\
\hline & Grup içindeki \% (\% within group) & 5.8 & 85.5 & 8.7 & 100.0 \\
\hline & Birlik içindeki \% (\% within association) & 4.3 & 35.1 & 5.6 & 18.7 \\
\hline \multicolumn{2}{|l|}{$\mathrm{x}^{2}=112.311$} & \multicolumn{4}{|c|}{$p=0,000$} \\
\hline
\end{tabular}

Tarımsal örgüte üye olan üreticilere, tarımsal örgütün başarılı olması için neler yapılması gerektiği sorulduğunda üreticilerin büyük bölümü, tarımsal örgütlerin pazarlama ve ucuz girdi sağlama konusunda daha aktif olmasını istediklerini belirtmişlerdir (Aydoğan ve Yulaf̧̧ı, 2014).

Erzurum'da yapılan bir çalışmada üretici örgütlerine üye olanların \% 57.14‘ü birliklerin etkin bir pazarlama yapmadığını, \% 28.57'si etkin pazarlama yaptığını belirtirken \% $14.29^{‘} \mathrm{u}$ ise kararsiz olduğunu beyan etmiştir. Üyelerin \% 60.71'i birliklerin ürünlerine katma değer kazandırmadığını dile getirmiştir (Sarı, 2016). Uşak'ta yapılan çalışmada, sadece tüccarlar aracılığıyla ürün pazarlayan üreticiler \% 53.4'dür. Ürünlerini pazarda sattığını söyleyenlerin oranı ise \% 11.3’tür. Örgütler aracılığıyla pazarlayan üyelerin oranı \% 19.7'dir (Sağlam, 2013).

İstatistiksel olarak, üye olunan örgüt ile pazarlama durumu arasındaki ilişki tüm pazarlama yolları için farklılaşmaktadır. Her birlik üretim şekline, yetiştirme tekniğine göre kendine has bir pazarlama yönteminde yoğunlaşmış görünmektedir.

Çizelge 6, yetiştiricilerin üye olmadan önce birliklerden haberdar olma durumlarını göstermektedir. Üye olmadan önce birliklerden haberdarım diyenlerin oranı \% 34.7 haberdar değilim diyenlerin oranı ise \% 65.3’tür. Bir başka deyişle birlik üyelerinin yarısından fazlası birliklerden ancak üye olma aşamasında haberdar olmuşlardır. Ancak bu oran \% 72 ile DKKYB üyeleri için oldukça fazladır. DSYB üyelerinin \% 47.9'u, AYB üyelerinin \%33.6, DKKYB üyelerinin ise \% 28 'i üye olmadan önce birlikler ile ilgili bilgi sahibidir. Birlikler ile üye olmadan önce birliklerden haberdar olma durumu üye olunan birlikten bağımsız değildir. $\mathrm{Bu}$ bağımlılık halinin DSYB üyelerinin durumundan kaynaklandığ söylenebilir.

Yetiştiricilerin birlikler ile ilgili bilgi kaynakları ile ilgili durum Çizelge 7'de verilmiştir. İl/İlce Tarım ve
Orman Müdürlüklerinden bilgi alma konusunda AYB üyeleri \% 45.7 ile ilk sıradadır. Bilgi kaynağı danışman olan üyeler açısından ise DKKYB üyeleri \% 66.2 ile en yüksek dilimi oluşturmaktadır. Yine AYB üyeleri \% 87.5 ile bilgi kaynağı İnternet/TV olan grup içerisinde çok büyük bir çoğunluğu oluşturmaktadır. Genel toplamda ise yetiştiricilerin bilgi kaynaklarında ilk sırayı \% 42.3 ile başka bir çiftçi/çevre seçeneği almaktadır, il/ilçe müdürlükleri ise $\% 35$ ile ikinci sırada yer almaktadır. Genel toplam içerisinde en düşük pay \% 2.2 ile internet/tv seçeneğidir.

Farklı birliklere üye yetiştiricilerin bilgi kaynakları açısından aralarında istatistiksel olarak \% 5 düzeyinde bir farklılık olduğu Çizelge 8'de görülmektedir. Farklılığın kaynağı ise Çizelge 9'da verilmiştir. AYB üyelerinin eğitim seviyelerin yüksekliği, kamu kuruluşlarında çalışıyor olmaları internet ile bilgiye erişim oranını bu gurup için artırmaktadır. Bu grup aynı zamanda diğer yetiştirici gruplarına göre faaliyetin dönemsel olması nedeniyle kurumları ziyaret edecek daha çok vakit bulmaktadırlar.

Üye olma aşamasında etkili faktör ile ilgili soruya verilen yanıtlar Çizelge 10 'da görülmektedir. Birliklerin kurucuları ve yetiştiricinin arkadaş çevresinin etkisi ile üye olanların oranı \% 15.7 ile eşit görülmektedir. Danışmanların en etkili olduğu birlik DKKYB'dir. Danışmanlar aynı zamanda DKKYB üyeleri için halk elinde ıslah projesinin de yürütücüleri olduklarından etkilidirler. Birlik kurucuları ise \% 41.4 ile DSYB üyeleri üzerinde en çok etkili olan faktördür.

Bakanlık tarafından yetiştiricilere ödenen desteklemelerden yararlanabilmek için üye olduğunu belirtenler \% 38.8 ile ilk sirayı almaktadır. Samsun ilinde yapılan araştırmada, üreticilerin \% 59.3 desteklemelerden yararlanmak için bir tarımsal örgüte üye olduklarını belirtmişlerdir (Aydoğan ve Yulafçı, 2014). 
Çizelge 6. Üye olmadan önce birliklerden haberdar olma durumu

Table 6. The status of being aware of the associations before becoming a member

\begin{tabular}{|c|c|c|c|c|c|}
\hline \multirow{2}{*}{\multicolumn{2}{|c|}{$\begin{array}{l}\text { Haberdar Olma Durumu } \\
\text { Awareness Status }\end{array}$}} & \multicolumn{3}{|c|}{$\begin{array}{c}\text { Yetiştirici Birlikleri } \\
\text { (Breeder Associations) }\end{array}$} & \multirow{3}{*}{$\begin{array}{c}\begin{array}{c}\text { Toplam } \\
\text { Total }\end{array} \\
128 \\
\end{array}$} \\
\hline & & \multirow{2}{*}{$\begin{array}{c}\text { DSYB } \\
45 \\
\end{array}$} & \multirow{2}{*}{$\begin{array}{c}\text { DKKYB } \\
47 \\
\end{array}$} & \multirow{2}{*}{$\begin{array}{c}\mathrm{AYB} \\
36 \\
\end{array}$} & \\
\hline \multirow{4}{*}{$\begin{array}{l}\text { Evet } \\
Y e S\end{array}$} & Sayl $($ Count $)$ & & & & \\
\hline & Grup içindeki \% (\% within group) & 35.2 & 36.7 & 28.1 & 100.0 \\
\hline & Birlik içindeki \% (\% within association) & 47.9 & 28.0 & 33.6 & 34.7 \\
\hline & Genel \% (General) & 12.2 & 12.7 & 9.8 & 34.7 \\
\hline \multirow{4}{*}{$\begin{array}{l}\text { Hayır } \\
\text { No }\end{array}$} & Sayı $($ Count $)$ & 49 & 121 & 71 & 241 \\
\hline & Grup içindeki \% (\% within group) & 20.3 & 50.2 & 29.5 & 100.0 \\
\hline & Birlik içindeki \% (\% within association) & 52.1 & 72.0 & 66.4 & 65.3 \\
\hline & Genel \% (General) & 13.3 & 32.8 & 19.2 & 65.3 \\
\hline \multicolumn{2}{|c|}{$x^{2}=10.604$} & & & $p=0.00$ & \\
\hline
\end{tabular}

Çizelge 7. Yetiştiricilerin birlikler ile ilgili bilgi kaynakları

Table 7. Information sources related to breeders' associations

\begin{tabular}{|c|c|c|c|c|c|}
\hline \multirow{2}{*}{\multicolumn{2}{|c|}{$\begin{array}{l}\text { Bilgi Kaynakları } \\
\text { Information Resources }\end{array}$}} & \multicolumn{3}{|c|}{$\begin{array}{l}\text { Yetiştirici Birlikleri } \\
\text { Breeder Associations }\end{array}$} & \multirow{3}{*}{$\begin{array}{c}\begin{array}{c}\text { Toplam } \\
\text { Total }\end{array} \\
129\end{array}$} \\
\hline & & \multirow{2}{*}{$\frac{\text { DSYB }}{22}$} & \multirow{2}{*}{\begin{tabular}{|c|} 
DKKYB \\
48
\end{tabular}} & \multirow{2}{*}{$\begin{array}{c}\text { AYB } \\
59\end{array}$} & \\
\hline İl/İlce Müdürlüğü & Sayı (Count) & & & & \\
\hline Provincial / District & Grup içindeki \% (within group) & 17.1 & 37.2 & 45.7 & 100.0 \\
\hline Directorate & Birlik içindeki \% (within association) & 23.4 & 28.6 & 55.1 & 35.0 \\
\hline & Genel \% (General) & 6.0 & 13.0 & 16.0 & 35.0 \\
\hline \multirow{4}{*}{$\begin{array}{l}\text { Danışman } \\
\text { Consultant }\end{array}$} & Sayı $($ Count $)$ & 14 & 43 & 8 & 65 \\
\hline & Grup içindeki \% (within group) & 21.5 & 66.2 & 12.3 & 100.0 \\
\hline & Birlik içindeki \% (within association) & 14.9 & 25.6 & 7.5 & 17.6 \\
\hline & Genel \% (General) & 3.8 & 11.7 & 2.2 & 17.6 \\
\hline \multirow{4}{*}{ Internet/TV } & Sayı (Count) & 0 & 1 & 7 & 8 \\
\hline & Grup içindeki \% (within group) & 0.0 & 12.5 & 87.5 & 100.0 \\
\hline & Birlik içindeki \% (within association) & 0.0 & 0.6 & 6.5 & 2.2 \\
\hline & Genel \% (General) & 0.0 & 0.3 & 1.9 & 2.2 \\
\hline \multirow{4}{*}{$\begin{array}{l}\text { Çiftçi/Çevre } \\
\text { Farmers / } \\
\text { Relativest }\end{array}$} & Sayı (Count) & 57 & 72 & 27 & 156 \\
\hline & Grup içindeki \% (within group) & 36.5 & 46.2 & 17.3 & 100.0 \\
\hline & Birlik içindeki \% (within association) & 60.6 & 42.9 & 25.2 & 42.3 \\
\hline & Genel \% (GeneraI) & 15.4 & 19.5 & 7.3 & 42.3 \\
\hline \multirow{4}{*}{$\begin{array}{l}\text { Diğer } \\
\text { Others }\end{array}$} & Sayı $($ Count $)$ & 1 & 4 & 6 & 11 \\
\hline & Grup içindeki \% (within group) & 9.1 & 36.4 & 54.5 & 100.0 \\
\hline & Birlik içindeki \% (within association) & 1.1 & 2.4 & 5.6 & 3.0 \\
\hline & Genel \% (GeneraI) & 0.3 & 1.1 & 1.6 & 3.0 \\
\hline \multirow{2}{*}{$\begin{array}{l}\text { Genel } \\
\text { General }\end{array}$} & Sayı (Count) & 94 & 168 & 107 & 369 \\
\hline & Toplam \% (TotaI) & 25.5 & 45.5 & 29.0 & 100.0 \\
\hline
\end{tabular}

Çizelge 8. Bilgi kaynaklarının birliklere göre farklılaşması Kruskal-Wallis testi tablosu

Table 8. Differentiation of information sources according to associations Kruskal-Wallis test table

\begin{tabular}{|c|c|c|c|c|c|}
\hline Birlik (Association) & $\mathrm{N}$ & Sira Ort. (Row average) & $\mathrm{SD}(D F)$ & $x^{2}$ & $\mathrm{p}$ \\
\hline DSYB & 94 & 213.30 & \multirow{4}{*}{2} & \multirow{4}{*}{19.587} & \multirow{4}{*}{0.000} \\
\hline DKKYB & 168 & 190.10 & & & \\
\hline AYB & 107 & 152.13 & & & \\
\hline Toplam (Total) & 369 & & & & \\
\hline
\end{tabular}


Çizelge 9. Yetiştiricilerin bilgi kaynakları Mann-Whitney U testi tablosu

Table 9. Information sources of breeders Mann-Whitney U test table

\begin{tabular}{|c|c|c|c|c|c|c|c|}
\hline \multirow{2}{*}{$\begin{array}{l}\text { Birlik } \\
\text { Association }\end{array}$} & \multirow[t]{2}{*}{$\mathrm{N}$} & \multicolumn{2}{|c|}{$\begin{array}{c}\text { Sira Sayıları } \\
\text { Row numbers } \\
\end{array}$} & \multirow{2}{*}{ Mann-Whitney U } & \multirow{2}{*}{ Wilcoxon W } & \multirow[t]{2}{*}{$\mathrm{Z}$} & \multirow{2}{*}{$\mathrm{P}$} \\
\hline & & $\begin{array}{l}\text { Ortalama } \\
\text { Average }\end{array}$ & $\begin{array}{c}\text { Toplam } \\
\text { Total }\end{array}$ & & & & \\
\hline DSYB & 94 & 142.85 & 13428.00 & \multirow{2}{*}{6829.000} & \multirow{2}{*}{21025.000} & \multirow{2}{*}{-1.966} & \multirow{2}{*}{.049} \\
\hline DKKYB & 168 & 125.15 & 21025.00 & & & & \\
\hline$\overline{\mathrm{DSYB}}$ & 94 & 117.95 & 11087.50 & \multirow{2}{*}{3435.500} & \multirow{2}{*}{9213.500} & \multirow{2}{*}{-4.176} & \multirow{2}{*}{.000} \\
\hline AYB & 107 & 86.11 & 9213.50 & & & & \\
\hline DKKYB & 168 & 149.45 & 25107.50 & \multirow[t]{2}{*}{7064.500} & \multirow[t]{2}{*}{12842.500} & \multirow[t]{2}{*}{-3.175} & \multirow[t]{2}{*}{.002} \\
\hline AYB & 107 & 120.02 & 12842.50 & & & & \\
\hline
\end{tabular}

Çizelge 10. Yetiştiricilerin birliklere üye olmasında etkili faktörler

Table 10. Factors affecting breeders' membership to associations

\begin{tabular}{|c|c|c|c|c|c|}
\hline \multirow{2}{*}{\multicolumn{2}{|c|}{ Etkili Faktör (Effective Factors) }} & \multicolumn{3}{|c|}{$\begin{array}{c}\text { Yetiştirici Birlikleri } \\
\text { Breeder Associations }\end{array}$} & \multirow{3}{*}{$\begin{array}{r}\begin{array}{l}\text { TOPLAM } \\
\text { TOTAL }\end{array} \\
15 \\
\end{array}$} \\
\hline & & DSYB & DKKYB & AYB & \\
\hline \multirow{4}{*}{$\begin{array}{l}\text { Aile } \\
\text { Family }\end{array}$} & Sayı (Count) & 3 & 7 & 5 & \\
\hline & Grup içindeki \% (within group) & 20.0 & 46.7 & 33.3 & 100.0 \\
\hline & Birlik içindeki \% (within association) & 3.2 & 4.2 & 4.7 & 4.1 \\
\hline & Genel \% (General) & 0.8 & 1.9 & 1.4 & 4.1 \\
\hline \multirow{4}{*}{$\begin{array}{l}\text { Arkadaş } \\
\text { Friends }\end{array}$} & Sayı (Count) & 18 & 31 & 9 & 58 \\
\hline & Grup içindeki \% (within group) & 31.0 & 53.4 & 15.5 & 100.0 \\
\hline & Birlik içindeki \% (within association) & 19.1 & 18.5 & 8.4 & 15.7 \\
\hline & Genel \% (General) & 4.9 & 8.4 & 2.4 & 15.7 \\
\hline \multirow{4}{*}{$\begin{array}{l}\text { Birlik Kurucuları } \\
\text { Association Founders }\end{array}$} & Sayı (Count) & 16 & 24 & 18 & 58 \\
\hline & Grup içindeki \% (within group) & 27.6 & 41.4 & 31.0 & 100.0 \\
\hline & Birlik içindeki \% (within association) & 17.0 & 14.3 & 16.8 & 15.7 \\
\hline & Genel \% (General) & 4.3 & 6.5 & 4.9 & 15.7 \\
\hline \multirow{4}{*}{$\begin{array}{l}\text { Danışman } \\
\text { Consultant }\end{array}$} & Sayı $($ Count $)$ & 11 & 37 & 6 & 54 \\
\hline & Grup içindeki \% (within group) & 20.4 & 68.5 & 11.1 & 100.0 \\
\hline & Birlik içindeki \% (within association) & 11.7 & 22.0 & 5.6 & 14.6 \\
\hline & Genel \% (General) & 3.0 & 10.0 & 1.6 & 14.6 \\
\hline \multirow{4}{*}{$\begin{array}{l}\text { Destekleme için } \\
\text { Yasal zorunluluk } \\
\text { Legal obligation for } \\
\text { support }\end{array}$} & Sayı $($ Count $)$ & 26 & 59 & 58 & 143 \\
\hline & Grup içindeki \% (within group) & 18.2 & 41.3 & 40.6 & 100.0 \\
\hline & Birlik içindeki \% (within association) & 27.7 & 35.1 & 54.2 & 38.8 \\
\hline & Genel \% (General) & 7.0 & 16.0 & 15.7 & 38.8 \\
\hline \multirow{4}{*}{$\begin{array}{l}\text { Diğer } \\
\text { Others }\end{array}$} & Sayı $($ Count $)$ & 20 & 10 & 11 & 41 \\
\hline & Grup içindeki \% (within group) & 48.8 & 24.4 & 26.8 & 100.0 \\
\hline & Birlik içindeki \% (within association) & 21.3 & 6.0 & 10.3 & 11.1 \\
\hline & Genel \% (General) & 5.4 & 2.7 & 3.0 & 11.1 \\
\hline
\end{tabular}

Çizelge 10'da üye olunan birlik ile üye olma aşamasında etkili olan faktörler arasında istatistiksel açıdan \% 1 anlamlılık düzeyinde bir fark olduğu görülmektedir. DKKYB üyeleri arasında danışman etkisi ile üye olma oranı \% 68.5 ile oldukça yüksektir. Birliklere üye olma aşamasında etkili faktör konusunda DKKYB'nin diğer birliklerden ayrıldığı söylenebilir. Desteklemelerden yararlanmak için üye olma seçeneği ise AYB üyeleri için fark yaratacak kadar öne çıkmaktadır.

Yetiştiricilerin üye oldukları birliklerin genel kurullarına katılım durumları Cizelge 11'de verilmiştir. Çizelge 11'e bakıldığında, tamamına katılıyorum diyenlerin \% 47.1'i AYB üyeleridir. Hiçbirine katılmadığını beyan edenlerin içerisinde ise DKKYB üyeleri \% 42.8 ile ilk siradadır. Bu yetiştiricilerin önemli bir bölümü yüz yüze anket esnasında aynı zamanda sürü bakıcısı oldukları için genel kurullara katılamadıklarını iletmişlerdir. Genel toplama bakıldığında ise tamamına katılıyorum diyenlerin oranı \% 18.4, hiçbirine katılmıyorum diyenlerin oranı ise neredeyse \% 40'tır (39.3). 
Çizelge 11. Yetiştiricilerin birlik genel kurullarına katılım durumu

Table 11. The status of participation of breeders in general assemblies

\begin{tabular}{|c|c|c|c|c|c|}
\hline \multirow{2}{*}{\multicolumn{2}{|c|}{$\begin{array}{l}\text { Genel Kurullara Katılim } \\
\text { Participation in general assemblies }\end{array}$}} & \multicolumn{3}{|c|}{ Yetiştirici Birlikleri } & \multirow{2}{*}{$\begin{array}{l}\text { TOPLAM } \\
\text { TOTAL }\end{array}$} \\
\hline & & DSYB & DKKYB & AYB & \\
\hline \multirow{4}{*}{$\begin{array}{l}\text { Tamamina } \\
\text { All }\end{array}$} & Sayı (Count) & 13 & 23 & 32 & 68 \\
\hline & Grup içindeki \% (within group) & 19.1 & 33.8 & 47.1 & 100.0 \\
\hline & Birlik içindeki \%(within association) & 13.8 & 13.7 & 29.9 & 18.4 \\
\hline & Genel \% (General) & 3.5 & 6.2 & 8.7 & 18.4 \\
\hline \multirow{4}{*}{$\begin{array}{l}\text { Çoğuna } \\
\text { Most }\end{array}$} & Sayı $($ Count $)$ & 15 & 40 & 24 & 79 \\
\hline & Grup içindeki \% (within group) & 19.0 & 50.6 & 30.4 & 100.0 \\
\hline & Birlik içindeki \% (within association) & 16.0 & 23.8 & 22.4 & 21.4 \\
\hline & Genel \% (General) & 4.1 & 10.8 & 6.5 & 21.4 \\
\hline \multirow{4}{*}{$\begin{array}{l}\text { Çok azına } \\
\text { A few }\end{array}$} & Sayı (Count) & 22 & 43 & 12 & 77 \\
\hline & Grup içindeki (\% within group) & 28.6 & 55.8 & 15.6 & 100.0 \\
\hline & Birlik içindeki \% (within association) & 23.4 & 25.6 & 11.2 & 20.9 \\
\hline & Genel \% (General) & 6.0 & 11.7 & 3.3 & 20.9 \\
\hline \multirow{4}{*}{$\begin{array}{l}\text { Hiçbirine } \\
\text { Never }\end{array}$} & Sayı $($ Count $)$ & 44 & 62 & 39 & 145 \\
\hline & Grup içindeki \% (\% within group) & 30.3 & 42.8 & 26.9 & 100.0 \\
\hline & Birlik içindeki \% (\% within association) & 46.8 & 36.9 & 36.4 & 39.3 \\
\hline & Genel \% (GeneraI) & 11.9 & 16.8 & 10.6 & 39.3 \\
\hline \multirow{2}{*}{$\begin{array}{l}\text { Genel } \\
\text { General }\end{array}$} & Sayı (Count) & 94 & 168 & 107 & 369 \\
\hline & Toplam \% (TotaI) & 25.5 & 45.5 & 29.0 & 100.0 \\
\hline
\end{tabular}

Samsun'da yapılan çalışmada farklı üretici örgütlerinin genel kurullarına katılım konusunda \% 74.4 gibi olumlu bir sonuç çıkmıştır. Uşak'ta yapılan çalışmada ise "Hepsine Katılıyorum" diyenlerin oranı \% 10.8 ile Sivas'taki orandan daha düşüktür (Aydoğan ve Yulafçı, 2014.,Sağlam, 2013). "Çoğuna Katılıyorum” diyenler \% 11.1 ile yine Sivas'taki orandan (\% 21.4) çok daha düşüktür. "Hiç Katılmıyorum" diyenlerin oranı ise Uşak'ta \% 27.5'dir. \% 13.1'lik bir oran ise soruyu yanıtsız bırakmıştır (Sağlam, 2013).

Üye olunan birlik ile üyelerin genel kurullara katılım oranları arasında istatistiksel açıdan \% 5 anlamlılık düzeyinde bir ilişki olduğu Çizelge 11'de görülmektedir. Üye olunan birlik ile yetiştiricilerin genel kurullara katılımı birbirinden bağımsız değildir. AYB üyelerinin \% 29.9'u genel kurulların tamamına katılırken diğer birlik üyelerinde bu oran sırasıyla \% 13.7 ve 13.8 ile birbirine oldukça yakındır. AYB üyelerinin diğer birlik üyelerine göre iki kattan daha fazla katılım gösterdikleri görülmektedir. Genel kurulların çoğuna ve çok azına katılıyorum diyenler içerisinde DKKYB üyeleri sırasıyla \% 50.6 ve \% 55.8 ile diğer iki birlik üyelerinden oldukça yüksek orandadır.

Yetiştiricilerin birlik yönetimlerinde görev alma durumları Çizelge 12 'de verilmiştir. Üye olunan birliklerin yönetim kurullarında görev alma durumları incelendiğinde yetiştiricilerin \% 13.8'i görev aldığını ifade ederken \% 86.2' si görev almadığını belirtmiştir.
Görev almayanların içerisinde DKKYB üyeleri \% 47.8 ile en büyük oranı oluşturmaktadır. Samsundaki araştırmada üyelerin tarımsal örgütün yönetiminde \% 9.4 oranında görev aldıkları tespit edilmiştir (Aydoğan ve Yulafçı, 2014). Uşak'ta yapılan çalışmada ise araştırma kapsamındaki işletmelerin yönetimlerde görev alma oranı \% 11.9 olarak bulunmuştur (Sağlam, 2013).

Üye olunan birlik ile yetiştiricilerin birlik yönetim kurullarında görev almaları arasında istatistiksel olarak \% 10 düzeyinde bir farklılık olduğu Çizelge 12 'de görülmektedir. Tüm birlikler içerisinde yönetim kurullarında görev almayanların oranı \% 81.3 ile \% 90.5 arasında değişmektedir ve çok ciddi farklılıklar görülmemektedir.

Birliklerin görev ve sorumluluklarını biliyorum diyenlerin oranı Çizelge 13'de görülebileceği gibi sadece \% 23.6'dır. Birliklerin görev ve sorumluluklarını bilmeyen veya kısmen bilen yetiştiricilerin oranı ise \% 76.4'tür. Evet, biliyorum diyenlerin içerisinde DSYB üyeleri \% 28.7 ile en düşük oranı oluştururken, Hayır diyenlerin içerisinde DKKYB üyeleri \% 37.4 ile en yüksek oranı oluşturmaktadır. Üyelerin büyük çoğunluğunun görev ve sorumlulukları tam olarak bilmediği söylenebilir

Uşakta yapılan çalışmada ise üreticilere üye ya da ortak oldukları tarımsal üretici örgütünün ana sözleşmesini okuyup okumadıkları sorulmuştur. Bu tür örgütleri tanımlayan, çalışma konularını, hak ve 
yetkilerini belirleyen temel belge ana sözleşme ya da tüzüktür. Üreticilerden sadece \% 20.3'lük kısmı ana sözleşmeyi okuduğunu bildirmiştir (Sağlam, 2013).

Üye olunan birlik ile üyelerin birliklerin görev ve yetkilerini bilme durumları olduğunu, farklı birlikler durumlarının birbirinden görülmektedir.

Çizelge 12. Yetiştiricilerin birlik yönetimlerinde görev alma durumu

Table 12. Status of breeders to take part in union management

\begin{tabular}{|c|c|c|c|c|c|}
\hline \multirow{2}{*}{\multicolumn{2}{|c|}{$\begin{array}{l}\text { Yönetimde Görev Alma } \\
\text { Take part in union management }\end{array}$}} & \multicolumn{3}{|c|}{$\begin{array}{l}\text { Yetiştirici Birlikleri } \\
\text { Breeder Associations }\end{array}$} & \multirow{3}{*}{$\begin{array}{l}\text { TOPLAM } \\
\text { TOTAL } \\
\\
51\end{array}$} \\
\hline & & DSYB & DKKYB & AYB & \\
\hline \multirow{4}{*}{$\begin{array}{l}\text { Evet } \\
\text { Yes }\end{array}$} & Sayı (Count) & 15 & 16 & 20 & \\
\hline & Grup içindeki \% (\% within group) & 29.4 & 31.4 & 39.2 & 100.0 \\
\hline & Birlik içindeki \% (\% within association) & 16.0 & 9.5 & 18.7 & 13.8 \\
\hline & Genel \% (General) & 4.1 & 4.3 & 5.4 & 13.8 \\
\hline \multirow{4}{*}{$\begin{array}{l}\text { Hayır } \\
\text { No }\end{array}$} & Sayı (Count) & 79 & 152 & 87 & 318 \\
\hline & Grup içindeki \% (\% within group) & 24.8 & 47.8 & 27.4 & 100.0 \\
\hline & Birlik içindeki \% (\% within association) & 84.0 & 90.5 & 81.3 & 86.2 \\
\hline & Genel \% (General) & 21.4 & 41.2 & 23.6 & 86.2 \\
\hline
\end{tabular}

Çizelge 13. Yetiştiricilerin birliklerin görev ve yetkileri ile ilgili bilgi durumu

Table 13. Status of breeders information about the duties and powers of the unions

\begin{tabular}{|c|c|c|c|c|c|}
\hline \multirow{2}{*}{\multicolumn{2}{|c|}{$\begin{array}{l}\text { Bilgi Durumu } \\
\text { Information Status }\end{array}$}} & \multicolumn{3}{|c|}{$\begin{array}{l}\text { Yetiştirici Birlikleri } \\
\text { Breeder Associations }\end{array}$} & \multirow{3}{*}{$\begin{array}{l}\begin{array}{l}\text { TOPLAM } \\
\text { TOTAL }\end{array} \\
87\end{array}$} \\
\hline & & \multirow{2}{*}{$\begin{array}{r}\text { DSYB } \\
25\end{array}$} & \multirow{2}{*}{$\begin{array}{r}\text { DKKYB } \\
31\end{array}$} & \multirow{2}{*}{$\begin{array}{l}\text { AYB } \\
31\end{array}$} & \\
\hline \multirow{4}{*}{$\begin{array}{l}\text { Biliyorum } \\
\text { Do know }\end{array}$} & Sayı (Count) & & & & \\
\hline & Grup içindeki \% (within group) & 28.7 & 35.6 & 35.6 & 100.0 \\
\hline & Birlik içindeki \% (within association) & 26.6 & 18.5 & 29.0 & 23.6 \\
\hline & Genel \% (General) & 6.8 & 8.4 & 8.4 & 23.6 \\
\hline \multirow{4}{*}{$\begin{array}{l}\text { Bilmiyorum } \\
\text { Does not } \\
\text { know }\end{array}$} & Sayı (Count) & 36 & 40 & 31 & 107 \\
\hline & Grup içindeki \% (within group) & 33.6 & 37.4 & 29.0 & 100.0 \\
\hline & Birlik içindeki \% (within association) & 38.3 & 23.8 & 29.0 & 29.0 \\
\hline & Genel \% (GeneraI) & 9.8 & 10.8 & 8.4 & 29.0 \\
\hline \multirow{4}{*}{$\begin{array}{l}\text { Kismen } \\
\text { Biliyorum } \\
\text { Partly Know }\end{array}$} & Sayı $($ Count $)$ & 33 & 97 & 45 & 175 \\
\hline & Grup içindeki \% (within group) & 18.9 & 55.4 & 25.7 & 100.0 \\
\hline & Birlik içindeki \% (within association) & 35.1 & 57.7 & 42.1 & 47.4 \\
\hline & Genel \% (General) & 8.9 & 26.3 & 12.2 & 47.4 \\
\hline \multirow{2}{*}{ Genel } & Sayı (Count) & 94 & 168 & 107 & 369 \\
\hline & Toplam \% (Total) & 25.5 & 45.5 & 29.0 & 100.0 \\
\hline \multicolumn{5}{|c|}{$\mathrm{x}^{2}=15.345 \quad \mathrm{SD}(\mathrm{DF})=4$} & $p=0.004$ \\
\hline
\end{tabular}

Birliklerin üyelerine yönelik eğitim verme durumları Çizelge 14'te incelenmiştir. Çizelgede AYB üyelerinin eğitim alanlar içerisinde \% 44.2 ile ilk sırada yer aldığı görülmektedir. DKKYB üyelerinin \% 75'i, DSYB üyelerinin ise \% 77.7'si birliklerinden herhangi bir eğitim almadıklarını belirtmiştir.

Tarımsal işletmelerin örgütlenme durumu ve buna etki eden faktörlerin belirlenmesi amacryla Erzurum'da yapılan çalışmada, tarımsal örgütlere üye olanların \% 67.85\% $\mathrm{i}$ birliklerin tarımsal yenilikler hakkında kendilerine bilgilendirme yapmadıklarını ifade etmiştir. Sadece \% 25‘i birliklerin üyelere bilgilendirme yaptığını belirtmiştir. Aynı çalışmada üreticiler \% 60.71 gibi yüksek bir oranla üye oldukları birliklerin kendilerine yeni politikalar hakkında bilgilendirme yapmadığını beyan etmişlerdir. Yeni politikalar ile ilgili örgütlerden bilgilendirme yapıldığını beyan edenlerin oranı ise $\% 32.14$ olmuştur. Konu ile ilgili beyanda bulunmayanlar ise \% 7.14'tür (Sarı, 2016).

Ki-kare analizi sonucu Çizelge 14'te görülebileceği gibi üye olunan birlik ile üyelerin birliklerden eğitim alma durumları arasındaki farklılığın istatistiksel olarak \% 1 düzeyinde anlamlı olduğu belirlenmiştir. Eğitim 
alanlar içerisinde en yüksek oran AYB üyelerine aittir. Arıcılığın sezonluk bir faaliyet olduğu değerlendirildiğinde AYB üyelerinin arıcılık faaliyetleri açısından ölü sezon olarak nitelendirilecek sezonda birlikler tarafından eğitime tabi tutulabilmeleri için daha fazla zamana sahip oldukları bilinmektedir. Özellikle küçükbaş hayvan yetiştiriciliğinin çok daha fazla zaman gerektirdiği ve yetiştiricilik faaliyetinin tüm yıla yayıldığ düşünüldüğünde hem birliklerin eğitim organizasyonu hem de yetiştiricilerin katılımı açısından kısıtlayıcı bir etkisi olduğunu kabul etmek gerekir.

Çizelge 14. Yetiştiricilerin birliklerden eğitim alma durumu

Table 14. Receiving training of breeders from associations

\begin{tabular}{|c|c|c|c|c|c|}
\hline \multirow{2}{*}{\multicolumn{2}{|c|}{$\begin{array}{l}\text { Eğitim Alma Durumu } \\
\text { Receiving Training }\end{array}$}} & \multicolumn{3}{|c|}{ Yetiştirici Birlikleri } & \multirow{2}{*}{$\begin{array}{l}\text { TOPLAM } \\
\text { TOTAL }\end{array}$} \\
\hline & & DSYB & DKKYB & AYB & \\
\hline \multirow{4}{*}{$\begin{array}{l}\text { Ĕgitim } \\
\text { Aldım } \\
\text { Yes }\end{array}$} & Sayı & 21 & 42 & 50 & 113 \\
\hline & Grup içindeki \% (within group) & 18.6 & 37.2 & 44.2 & 100.0 \\
\hline & Birlik içindeki \% (within association) & 22.3 & 25.0 & 46.7 & 30.6 \\
\hline & Genel \% (General) & 5.7 & 11.4 & 13.6 & 30.6 \\
\hline \multirow{4}{*}{$\begin{array}{l}\text { Ĕgitim } \\
\text { Almadım } \\
N_{o}\end{array}$} & Sayı (Count) & 73 & 126 & 57 & 256 \\
\hline & Grup içindeki \% (within group) & 28.5 & 49.2 & 22.3 & 100.0 \\
\hline & Birlik içindeki \% (within association) & 77.7 & 75.0 & 53.3 & 69.4 \\
\hline & Genel \% (General) & 19.8 & 34.1 & 15.4 & 69.4 \\
\hline \multirow{2}{*}{$\begin{array}{l}\text { Genel } \\
\text { General }\end{array}$} & Sayı (Count) & 94 & 168 & 107 & 369 \\
\hline & Toplam \% (Total) & 25.5 & 45.5 & 29.0 & 100.0 \\
\hline \multicolumn{2}{|l|}{$\mathrm{x}^{2}=18.600$} & $=2$ & & & $p=0.000$ \\
\hline
\end{tabular}

Birliklerin başarı durumlarına ilişkin üyelerin düşünceleri Çizelge 15’te verilmiştir. Birlikleri çok başarılı bulan üyelerin oranı oldukça düşüktür (\% 0.8$)$. Başarılı bulanların oranı \% 32.8, başarısız diyenler ise \% 37.7'dir. Üye oldukları birlikleri başarısız bulanların içerisinde DSYB üyeleri \% 48.9 ve çok başarısız diyenler içerisinde de \% 13.8 ile ilk sıradadır. Yetiştiricilerin üye oldukları birliklerin başarı durumlarını değerlendirmeleri arasında bir farklılık olduğu Khi Kare analizi sonucu tespit edilmiştir.

Birliklerini başarılı bulan grup içerisinde DKKYB üyesi yetiştiriciler \% 49.6 ile ilk sırda yer almaktadır ve diğer iki birlik üyelerinin toplamına yakın bir orandır. Bu sonuç DKKYB'nin Bakanlık desteği ile çalışma bölgesinde yürüttüğü 'Halk Elinde Islah' projesinden kaynaklandığı yüz yüze anket çalışmaları esnasında yetiştiriciler tarafından ifade edilmiştir. Yetiştiriciler çalışma alanında bu proje ile DKKYB'ni özdeşleştirmiş durumdadır. Fikir beyan etmeyen grup içerisinde de DKKYB üyeleri \%61.5 ile çok yüksek bir orana sahiptir.

Aynı şekilde projede yer alamayanlar ile birlik faaliyetlerine uzak olan yetiştiricilerin yanıtları nedeniyle bu oranın bu kadar yüksek çıktığı söylenebilir. Fikir beyan etmeyenler içerisinde DSYB üyeleri \% 6.4 ile diğer birliklere göre çok düşük bir orandadır. DSYB üyelerinin \% 48.9'u birliklerini başarısız bulduklarını beyan ederek diğer birliklerden ayrılmışlardır. DSYB'den beklenen hizmetlerin, süt toplama ve suni tohumlama gibi, günlük yerine getirilmesi gereken hizmetler olması yetiştirici memnuniyetlerini ciddi şekilde etkilemektedir.
Isparta'da yapılan bir çalışmada, ildeki DSYB üyelerinin \% 68.22'sinin verilen hizmetlerinden memnun olmadığı için üyelikten istifa ettiğini görülmüştür. Aynı çalışmada üyelerin \% 59.4'ü beklentilerinin karşılanmadığını, \% 20.3'ü ise beklentilerinin karşılandığını belirtmiştir (Akkurt ve Köknaroğlu, 2016). Aydoğan ve Yulafçı (2014) tarafından Samsun'da yapılan çalışmada, tarımsal örgüt size göre başarılı mıdır sorusuna evet diyenlerin oranı \% 51.8 olarak bulunmuştur.

Uşak'ta yapılan çalışmada damızlık yetiştirici birliklerini başarılı ve çok başarılı bulanların oranı \% 6.6, başarısız ve çok başarısız bulanların oranı ise \% 25.7'dir (Sağlam, 2013). Üreticilerin tarımsal üretici örgütlerine üye (ortak) olmaktan doğan memnuniyet dereceleri incelendiğinde çok memnunum diyenler \% 6.9 , memnunum diyenler \% 32.2, kısmen memnunum diyenler \% 24.4, memnun değilim diyenler \% 11.4 ve hiç memnun değilim diyenler ise \% 12.8 oranındadır (Sağlam, 2013).

Edirne'de yapılan çalışmada ise birliğin genel faaliyetleri hakkında üyelerin \% 63'ü memnuniyet ifade etmiştir (Karaturhan ve ark., 2014). Farklı illerde yapılan çalışmalarda üretici örgütlerinin başarıları ile ilgili olarak üreticilerin çok farklı düşüncelere sahip oldukları görülmektedir.

Çizelge 16 'da yetiştiricilerin yatırımla ilgili düşüncelerine yer verilmiştir. Yetiştiricilerin \% 52.6'sı faaliyet alanları ile ilgili yatırım yapmayı düşündüklerini \% 37.1'i yatırım yapmayacaklarını, \% 10.3'ü ise yatırım konusunda kararsız olduklarını bildirmiştir. Yatırım kararları ile üye olunan birlikler arasında istatistiksel olarak farklılık görülmemiştir. 
Çizelge 15. Yetiştiricilerin birliklerin başarı durumuna ilişkin düşünceleri

Table 15. The opinions of breeders on the success of the associations

\begin{tabular}{|c|c|c|c|c|c|}
\hline \multirow{2}{*}{\multicolumn{2}{|c|}{ Başarı Durumu (Success Status) }} & \multicolumn{2}{|c|}{$\begin{array}{l}\text { Yetiştirici Birlikleri } \\
\text { Breeder Associations }\end{array}$} & \multicolumn{2}{|c|}{$\begin{array}{c}\text { TOPLAM } \\
\text { TOTAL }\end{array}$} \\
\hline & & DSYB & \begin{tabular}{l|l} 
KKYB & \\
\end{tabular} & AYB & \\
\hline \multirow{4}{*}{$\begin{array}{l}\text { Çok Başarılı } \\
\text { Very successful }\end{array}$} & Sayı (Count) & 1 & 2 & 0 & 3 \\
\hline & Grup içindeki \% (within group) & 33.3 & 66.7 & 0.0 & 100.0 \\
\hline & Birlik içindeki \% (within association) & 1.1 & 1.2 & 0.0 & 0.8 \\
\hline & Genel \% (General) & 0.3 & 0.5 & 0.0 & 0.8 \\
\hline \multirow{4}{*}{$\begin{array}{l}\text { Başarılı } \\
\text { Successful }\end{array}$} & Sayı (Count) & 28 & 60 & 33 & 121 \\
\hline & Grup içindeki \% (within group) & 23.1 & 49.6 & 27.3 & 100.0 \\
\hline & Birlik içindeki \% (within association) & 29.8 & 35.7 & 30.8 & 32.8 \\
\hline & Genel \% (General) & 7.6 & 16.3 & 8.9 & 32.8 \\
\hline \multirow{4}{*}{$\begin{array}{l}\text { Fikrim yok } \\
\text { No idea }\end{array}$} & Sayı (Count) & 6 & 40 & 19 & 65 \\
\hline & Grup içindeki \% (within group) & 9.2 & 61.5 & 29.2 & 100.0 \\
\hline & Birlik içindeki \% (within association) & 6.4 & 23.8 & 17.8 & 17.6 \\
\hline & Genel \% (General) & 1.6 & 10.8 & 5.1 & 17.6 \\
\hline \multirow{4}{*}{$\begin{array}{l}\text { Başarısız } \\
\text { Unsuccessful }\end{array}$} & Sayı (Count) & 46 & 51 & 42 & 139 \\
\hline & Grup içindeki \% (within group) & 33.1 & 36.7 & 30.2 & 100.0 \\
\hline & Birlik içindeki \% (within association) & 48.9 & 30.4 & 39.3 & 37.7 \\
\hline & Genel \% (General) & 12.5 & 13.8 & 11.4 & 37.7 \\
\hline \multirow{4}{*}{$\begin{array}{l}\text { Çok başarısız } \\
\text { Very unsuccessful }\end{array}$} & Sayı (Count) & 13 & 15 & 13 & 41 \\
\hline & Grup içindeki \% (within group) & 31.7 & 36.6 & 31.7 & 100.0 \\
\hline & Birlik içindeki \% (within association) & 13.8 & 8.9 & 12.1 & 11.1 \\
\hline & Genel \% (General) & 3.5 & 4.1 & 3.5 & 11.1 \\
\hline \multirow{2}{*}{$\begin{array}{l}\text { Genel } \\
\text { General }\end{array}$} & Sayı (Count) & 94 & 168 & 107 & 369 \\
\hline & Toplam \% (Total) & 25.5 & 45.5 & 29.0 & 100.0 \\
\hline $\mathrm{x}^{2}=19.524$ & $\mathrm{SD}(\mathrm{DF})=8$ & \multicolumn{4}{|c|}{ p değeri $=0.012$} \\
\hline
\end{tabular}

Çizelge 16. Yetiştiricilerin yatırım yapmakla ilgili düşünceleri

Table 16. Breeders' thoughts about investing.

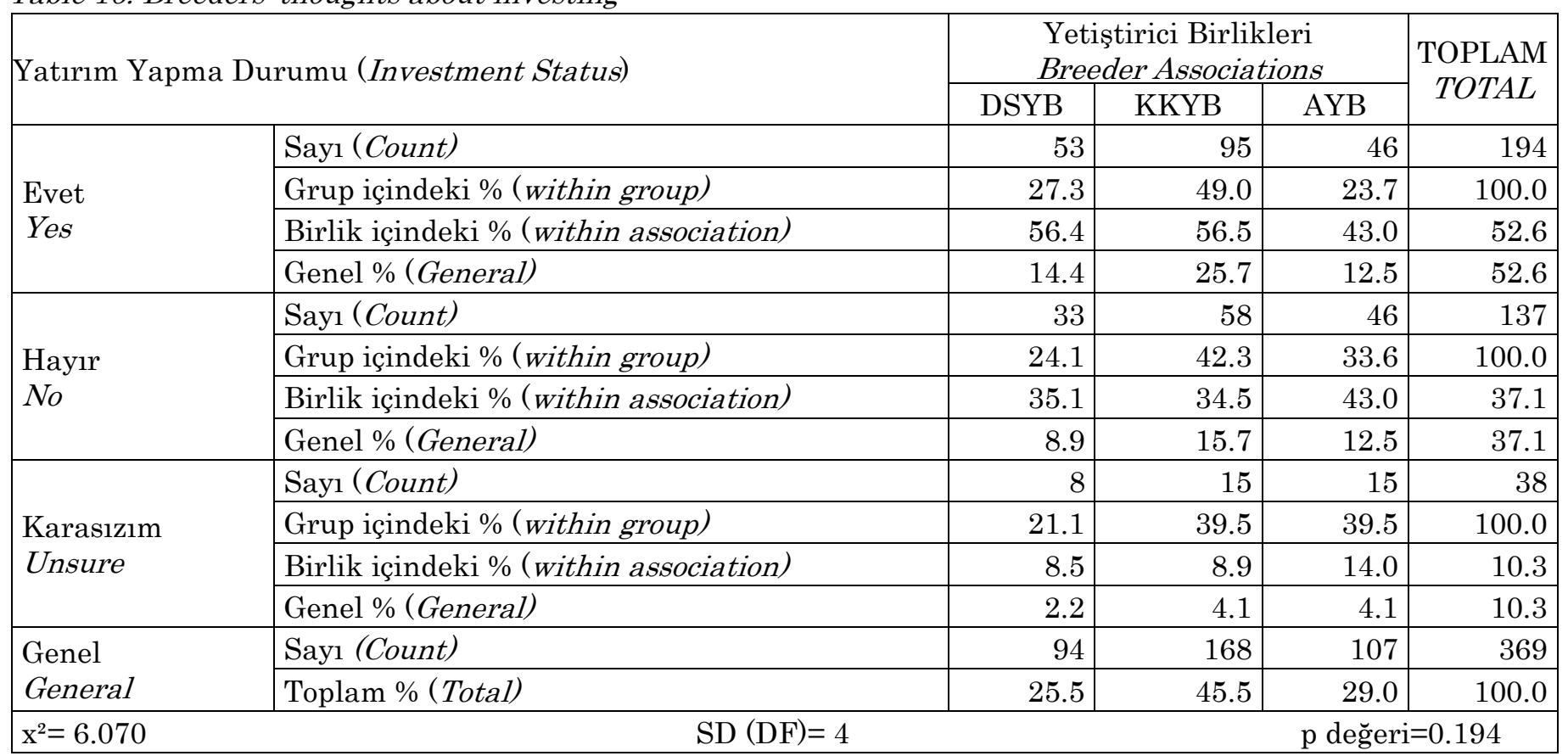

Çalışma kapsamında yer alan Sivas ilinde örgütlü 3 yetiştirici birliğine üye yetiştiricilerin eğitim durumlarına göre üye oldukları birliklerin genel kurullarına katılım durumları Çizelge 17'de 
verilmiştir. Eğitimi olmayan üyelerin birlik yönetimlerinin ve gelecek dönemde yapılması planlanan çalışmaların belirlendiği genel kurullara katılım konusunda diğer üyelere göre çok geride kaldıkları görülmektedir. Bu grupta genel kurulların hepsine veya çoğuna katılıyorum diyen hiçbir üyenin bulunmadiğı görülmektedir.

Çizelge 17. Yetiştiricilerin eğitim durumlarına göre genel kurullara katılım durumu

Table 17. The status of participation of the breeders in the general assemblies according to their educational status

\begin{tabular}{|c|c|c|c|c|c|c|}
\hline \multicolumn{2}{|l|}{ Ĕgitim Durumu } & Hepsin & Çoğuna & Çok azına & Hiçbirine & Toplam \\
\hline \multirow{4}{*}{$\begin{array}{l}\text { Eğitimi yok } \\
\text { No education }\end{array}$} & Sayı (Count) & 0 & 0 & 3 & 10 & 13 \\
\hline & Grup içindeki \% (within group) & 0.0 & 0.0 & 23.1 & 76.9 & 100.0 \\
\hline & Birlik içindeki \% (within association) & 0.0 & 0.0 & 3.9 & 6.9 & 3.5 \\
\hline & Genel \% (General) & 0.0 & 0.0 & 0.8 & 2.7 & 3.5 \\
\hline \multirow{4}{*}{$\begin{array}{l}\text { İlköğretim } \\
\text { Primary } \\
\text { education }\end{array}$} & Sayı (Count) & 43 & 59 & 44 & 98 & 244 \\
\hline & Grup içindeki \% (within group) & 17.6 & 24.2 & 18.0 & 40.2 & 100.0 \\
\hline & Birlik içindeki \% (within association) & 63.2 & 74.7 & 57.1 & 67.6 & 66.1 \\
\hline & Genel \% (General) & 11.7 & 16.0 & 11.9 & 26.6 & 66.1 \\
\hline \multirow{4}{*}{$\begin{array}{l}\text { Lise } \\
\text { High school }\end{array}$} & Sayı (Count) & 17 & 14 & 25 & 32 & 88 \\
\hline & Grup içindeki \% (within group) & 19.3 & 15.9 & 28.4 & 36.4 & 100.0 \\
\hline & Birlik içindeki \% (within association) & 25.0 & 17.7 & 32.5 & 22.1 & 23.8 \\
\hline & Genel \% (General) & 4.6 & 3.8 & 6.8 & 8.7 & 23.8 \\
\hline \multirow{5}{*}{$\begin{array}{l}\text { Yükseköğretim } \\
\text { Higher } \\
\text { education }\end{array}$} & Sayı (Count) & 8 & 6 & 5 & 5 & 24 \\
\hline & Grup içindeki \% (within group) & 33.3 & 25.0 & 20.8 & 20.8 & 100.0 \\
\hline & Birlik içindeki \% (within association) & 11.8 & 7.6 & 6.5 & 3.4 & 6.5 \\
\hline & Genel \% (General) & 2.2 & 1.6 & 1.4 & 1.4 & 6.5 \\
\hline & Genel (Total) & 68 & 79 & 77 & 145 & 369 \\
\hline
\end{tabular}

Yüksek öğretim mezunu olan üreticilerin \% 33.3’ü genel kurulların tamamina katılmaktadır. Hiçbirine katılmıyorum diyenlerin oranının yetiştiricilerin eğitim seviyeleri arttıkça azaldığı görülmektedir (sırasıyla \% 76.9, 40.2, 36.4, ve 20.8 dir). Eş deyişle, eğitim seviyesinin yüksekliği genel kurullara katılımı olumlu yönde etkilediği söylenebilir. Uşak'ta yapılan çalışmada genel kurullara hiç katılmayanların çoğunlukta olduğu görülmektedir. Genel kurulların hepsine katılanlardan ortaöğretim mezunu üreticilerin oranı diğerlerine göre bir miktar daha fazladır (Sağlam, 2013).

Eğitim durumları ile yetiştiricilerin genel kurullara katılımları arasında anlamlı bir farklılık olduğu görülmüştür. Analiz sonucu Çizelge 18'de görülmektedir.

Çizelge 18. Genel kurullara katılım-eğitim ilişkisi Kuruskall-Wallis testi tablosu

Table 18. The participation-education relationship in the General Assembly Kuruskall-Wallis test table

\begin{tabular}{|l|c|c|c|c|c|}
\hline Eğitim durumu (Education Status) & $\mathrm{N}$ & Sira Ort. (Row Average) & SD (DF) & \multirow{2}{*}{$\mathrm{X}^{2}$} & $\mathrm{p}$ \\
\hline Eğitimi yok (No education) & 13 & 271.38 & & & \\
\cline { 1 - 3 } İlköğretim (Primary school) & 244 & 185.02 & \multirow{3}{*}{3} & \multirow{3}{*}{14.184} & \multirow{2}{*}{0.003} \\
\cline { 1 - 3 } Lise (High school) & 88 & 184.69 & & & \\
\cline { 1 - 3 } & 24 & 139.13 & & & \\
\cline { 1 - 3 } Toplam (Total) & 369 & & & \\
\hline
\end{tabular}

Farklılı̆̆ın hangi eğitim gruplarından kaynaklandığını görebilmek için yetiştiriciler eğitim durumlarına göre ikişerli olarak Mann-Whitney U testi yapılmıştır. Yapılan testin sonuçları Çizelge 19'da verilmiştir. Gruplar arasında eğitim seviyesine bağlı farklılık arttıkça genel kurullara katılım oranı eğitimliler lehine değişmektedir.
Gelir durumlarına göre genel kurullara katılım durumlarını gösteren Çizelge 20'ye bakıldığında 50.000 TL den aşağı gelir olanların \% 50'den fazlası genel kurulların hiçbirine katılmadığını belirtmektedir. Toplamda ise yetiştiricilerin \% 39.3'ü genel kurulların hiçbirine katılmamaktadır. Genel kurulların tamamına katıldığını beyan edenlerin oranı $\%$ 18.4'tür ve bunun içerisinde en yüksek oranı \% 47'1 
ile 50.000 TL'den az geliri olanlardır. Ki- kare analizi yetiştiricilerin gelir grubu ile genel kurullara katılım arasında bir ilişki olduğunu göstermektedir. Daha az gelire sahip yetiştiricilerin genel kurullara katılımı daha yoğundur. Yetiştiricilerin gelirleri arttıkça genel kurullara katılım oranlarının düştügü görülmektedir. Bu yetiştiricilerin işletmeleri daha küçüktür ve büyük işletme sahibi yetiştiricilere göre başka bir gelir kaynağına sahip değildirler. Bu nedenle tek gelir kaynakları olan faaliyetleri ile daha çok ilgili oldukları söylenebilir. Büyük işletme sahiplerinin iş yoğunluğunun fazla olduğu ve yetiştiricilik faaliyetleri dışında uğraşlarının da olduğu çalışma sahasında gözlemlenmiştir.

Çizelge19. Genel kurullara katılım-eğitim ilişkisi Mann Whitney U testi

Table 19. Participation in the General Assembly-education relationship Mann Whitney U test

\begin{tabular}{|c|c|c|c|c|c|c|c|c|}
\hline \multirow{2}{*}{\begin{tabular}{|l} 
Genel \\
Kurul \\
Katılım \\
General \\
assembly
\end{tabular}} & \multirow[b]{2}{*}{$\begin{array}{l}\text { Birlik } \\
\text { Association }\end{array}$} & \multirow[b]{2}{*}{$\mathrm{N}$} & \multicolumn{2}{|c|}{ Sira Sayıları } & \multirow[b]{2}{*}{$\begin{array}{c}\text { Mann- } \\
\text { Whitney U }\end{array}$} & \multirow[b]{2}{*}{$\begin{array}{l}\text { Wilcoxon } \\
\text { W }\end{array}$} & \multirow[b]{2}{*}{$\mathbf{Z}$} & \multirow[b]{2}{*}{$\mathbf{P}$} \\
\hline & & & $\begin{array}{c}\text { Ortalama } \\
\text { Avarege }\end{array}$ & $\begin{array}{c}\text { Toplam } \\
\text { Total }\end{array}$ & & & & \\
\hline \multirow{2}{*}{ Grup 1} & Eğitimi yok (No training) & 13 & 185.62 & 2413.0 & \multirow{2}{*}{850.000} & \multirow{2}{*}{30740.000} & \multirow{2}{*}{-2.966} & \multirow{2}{*}{.003} \\
\hline & İlköğretim (Primary education) & 244 & 125.98 & 30740. & & & & \\
\hline \multirow{2}{*}{ Grup 2} & Eğitimi yok (No training) & 13 & 72.42 & 941.50 & \multirow{2}{*}{293.500} & \multirow{2}{*}{4209.500} & \multirow{2}{*}{-2.978} & \multirow{2}{*}{.003} \\
\hline & Lise (High school) & 88 & 47.84 & 4209.5 & & & & \\
\hline \multirow{2}{*}{ Grup 3} & Eğitimi yok (No training) & 13 & 27.35 & 355.50 & \multirow{2}{*}{47.500} & \multirow{2}{*}{347.500} & \multirow{2}{*}{-3.619} & \multirow{2}{*}{.000} \\
\hline & Yükseköğretim Higher education & 24 & 14.48 & 347.50 & & & & \\
\hline \multirow{2}{*}{ Grup 4} & İlköğretim (Primary school) & 244 & 166.56 & 40641. & \multirow{2}{*}{10720.500} & \multirow{2}{*}{14636.500} & \multirow{2}{*}{-.021} & \multirow{2}{*}{.98} \\
\hline & Lise (High school) & 88 & 166.32 & 14636. & & & & \\
\hline \multirow{2}{*}{ Grup 5} & İlköğretim (Primary school) & 244 & 137.48 & 33544. & \multirow{2}{*}{2202.000} & \multirow{2}{*}{2502.000} & \multirow{2}{*}{-2.094} & \multirow{2}{*}{.036} \\
\hline & Yükseköğretim Higher education & 24 & 104.25 & 2502.0 & & & & \\
\hline \multirow{2}{*}{ Grup 6} & Lise (High school) & 88 & 59.53 & 5238.5 & \multirow{2}{*}{789.500} & \multirow{2}{*}{1089.500} & \multirow{2}{*}{-1.962} & \multirow{2}{*}{.050} \\
\hline & Yükseköğretim Higher education & 24 & 45.40 & 1089.5 & & & & \\
\hline
\end{tabular}

Çizelge 20. Yetiştiricilerin gelir durumlarına göre genel kurullara katılım durumu

Table 20. Status of participation in general assemblies by breeders' income status

\begin{tabular}{|c|c|c|c|c|c|c|}
\hline \multirow{2}{*}{\multicolumn{2}{|c|}{$\begin{array}{l}\text { Gelir Durumu (TL) } \\
\text { Income }\end{array}$}} & \multicolumn{4}{|c|}{ Katılım Durumu } & \multirow{3}{*}{\begin{tabular}{|r|}
$\begin{array}{c}\text { Toplam } \\
\text { Total }\end{array}$ \\
183 \\
\end{tabular}} \\
\hline & & \multirow{2}{*}{$\begin{array}{c}\text { Hepsine } \\
\text { All } \\
32\end{array}$} & \multirow{2}{*}{$\begin{array}{l}\begin{array}{l}\text { Çoğuna } \\
\text { Most }\end{array} \\
27\end{array}$} & \multirow{2}{*}{$\begin{array}{l}\text { Çok azına } \\
\text { A few } \\
32\end{array}$} & \multirow{2}{*}{\begin{tabular}{|}
$\begin{array}{c}\text { Hiçbirine } \\
\text { None }\end{array}$ \\
92 \\
\end{tabular}} & \\
\hline \multirow{4}{*}{$0-50.000$} & Sayı (Count) & & & & & \\
\hline & Toplam içindeki \% (In total) & 17.5 & 14.8 & 17.5 & 50.3 & 100.0 \\
\hline & Grup içindeki \% (Within Group) & 47.1 & 34.2 & 41.6 & 63.4 & 49.6 \\
\hline & Genel \% (General) & 8.7 & 7.3 & 8.7 & 24.9 & 49.6 \\
\hline \multirow{4}{*}{$50.001-100.000$} & Sayı (Count) & 23 & 28 & 33 & 42 & 126 \\
\hline & Toplam içindeki \% (In total) & 18.3 & 22.2 & 26.2 & 33.3 & 100.0 \\
\hline & Grup içindeki \% (Within Group) & 33.8 & 35.4 & 42.9 & 29.0 & 34.1 \\
\hline & Genel \% (General) & 6.2 & 7.6 & 8.9 & 11.4 & 34.1 \\
\hline \multirow{4}{*}{$100.001+$} & Sayl (Count) & 13 & 24 & 12 & 11 & 60 \\
\hline & Toplam içindeki \% (In total) & 21.7 & 40.0 & 20.0 & 18.3 & 100.0 \\
\hline & Grup içindeki \% (Within Group) & 19.1 & 30.4 & 15.6 & 7.6 & 16.3 \\
\hline & Genel \% (General) & 3.5 & 6.5 & 3.3 & 3.0 & 16.3 \\
\hline \multirow{2}{*}{ GENEL } & Sayı (Count) & 68 & 79 & 77 & 145 & 369 \\
\hline & Toplam \% (Total) & 18.4 & 21.4 & 20.9 & 39.3 & 100.0 \\
\hline \multicolumn{2}{|l|}{$\mathrm{x}^{2}=30.139$} & & & $\mathrm{p}=0.000$ & & \\
\hline
\end{tabular}

Yetiştiricilerin mesleki deneyimlerine göre üye oldukları birliklerin genel kurullarına katılımları karşılaştırılmıştır.

Elde edilen sonuçlar Çizelge 21'de verilmiştir.
Sonuçlara bakıldığında, deneyim arttıkça genel kurullara katılımın arttığı aynı zamanda yetiştiricilerin mesleki deneyimi ile genel kurullara katılımları arasında bir farklılık olduğu 
görülmektedir.

Yetiştiricinin genel kurula katılımı mesleki deneyiminden bağımsız değildir. Bu durum en yüksek katılım oranı olan 26 yıl ve üzeri mesleki deneyime sahip yetiştiricilerden kaynaklandığı söylenebilir. Çizelge 21'de görülebileceği gibi bu grup içerisinde genel kurulların tamamına katılanların oranı \% 45.6 'dir.

26 yıl ve üzeri deneyimi olan bu yetiştirici grubu hayatının önemli bir bölümünü mevcut yetiştiricilik faaliyeti ile geçirmiştir ve bu faaliyetini meslek olarak benimsemiş olduğu görülmektedir.

Çizelge 21. Yetiştiricilerin mesleki deneyimlerine göre genel kurullara katılım durumu

Table 21. Participation' status in general assembly according to professional experience of breeders

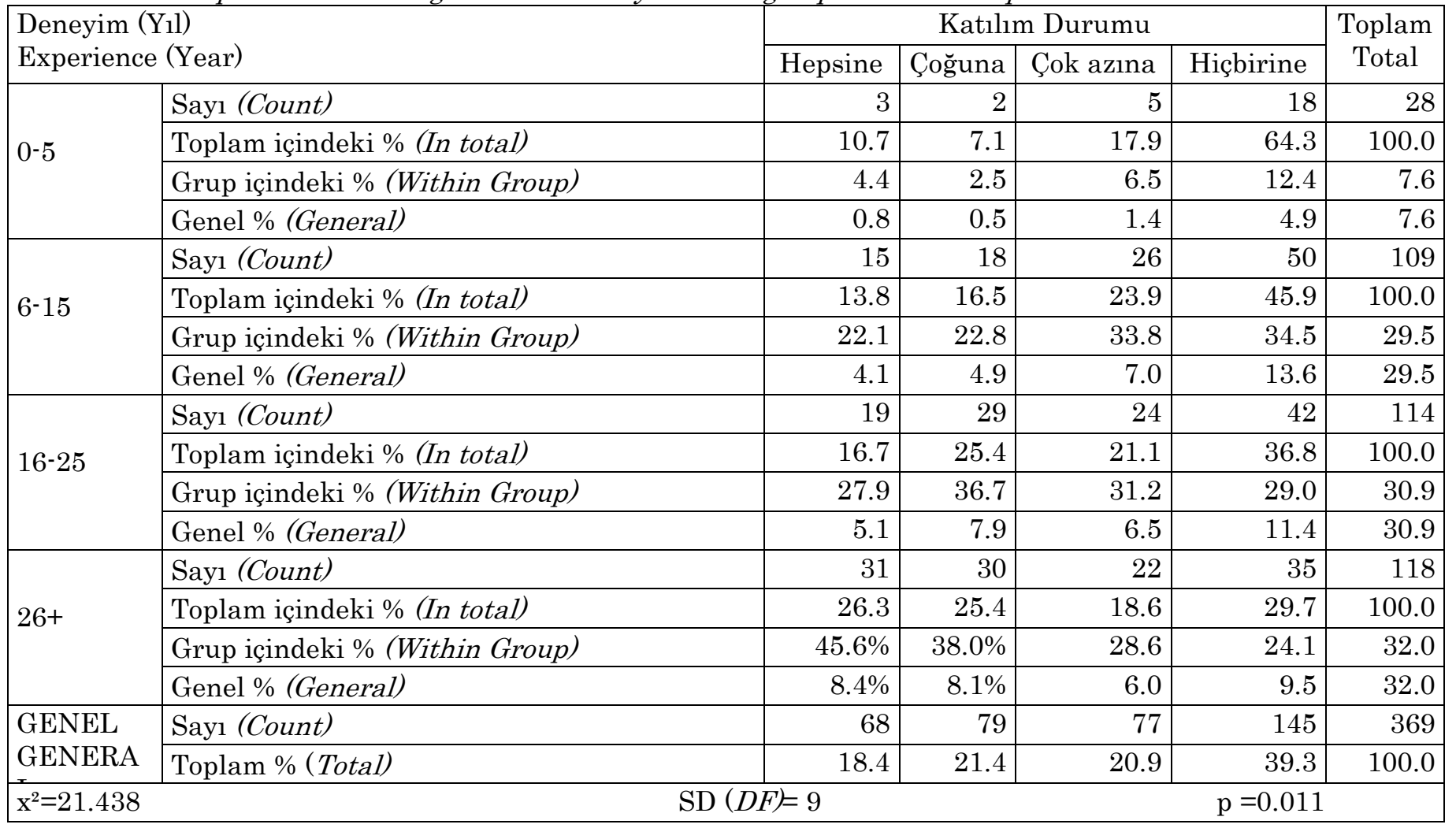

Birliklere üye yetiştiricilerin eğitim durumlarına göre birlik yönetim kurullarında görev alma durumları Çizelge 22'de verilmiştir. Birliklerin yönetimlerinde görev alanların büyük çoğunluğu (\% 62.7) ilköğretim mezunlarından oluşmaktadır. Eğitimi olmayanların ise hiç görev almadıkları görülmektedir.

Yükseköğretim mezunlarının içerisinde de birliklerin yönetimlerinde görev almayanların oranının (\% 87.5) oldukça yüksek olduğu söylenebilir. $\mathrm{Bu}$ gurup içerisinde tam zamanlı olarak başka bir işte çalışanların oranı oldukça yüksektir. Lise mezunu olanların içerisinde birliklerin yönetimlerinde görev almayanların oranı da \% 81.8'dir. Toplam üyelerin \% 86.2'si birlik yönetimlerinde görev almamışlardır.

Eğitim durumları ile genel kurullara katılım arasında fark olup olmadığını görebilmek için Kruskal-Wallis testi yapılmış ve sonuçlar Çizelge 23 'de verilmiştir.

Test sonucuna göre eğitim durumu ile birliklerin yönetimlerinde görev alma durumlarına arasinda istatistiksel olarak bir fark olmadığı görülmektedir.

Ancak eğitim seviyesi yüksek olanların düşük olanlara oranla yönetim kurullarında daha az yer aldıkları yönetimdeki işlerin daha çok ilköğretim mezunları tarafından yerine getirildiği söylenebilir. Eğitim durumu arttıkça yönetim kurullarında görev alma oranı düşmektedir.

Yetiştiricilerin gelirlerine göre yönetim kurullarında görev alma durumu Çizelge 24'te verilmiştir. Genel kurullara katılım açısından gelir grupları arasında anlamlı bir farklılık görünmemektedir. Genel olarak birliklerin yönetimlerinde görev alma oranı ise \% 13.8 olarak tespit edilmiştir. Ki- kare analiz sonuçlarına göre yetiştiricilerin gelirleri ile birliklerin yönetim kurullarında görev alma arasında bir farklılık yoktur. Ancak geliri yüksek olan grubun yönetim kurullarında görev alma oranlarının daha az gelire sahip gruplara göre biraz daha düşük olduğu söylenebilir. Bu durum büyük işletme sahiplerinin iş yoğunluğu ile açıklanabilir.

Anketin son sorusu yetiştiricilerin ucu açık olarak hazırlanmış ve yetiştiricilerden faaliyet alanlarına göre sorunlarını sıralamaları istenmiştir. Burada yetiştiricilerin belirtikleri ve genel olarak tüm yetiştiricileri etkilediği düşünülen sorunlar 3 farklı birlik üyeleri için ayrı ayrı ele alınmıştır. 
Çizelge 22. Yetiştiricilerin eğitimlerine göre yönetimde görev alma durumu

Table 22. Status of taking part in management according to education status of breeders

\begin{tabular}{|c|c|c|c|c|}
\hline \multirow{2}{*}{\multicolumn{2}{|c|}{$\begin{array}{l}\text { Eğitim Durumu } \\
\text { Education }\end{array}$}} & \multicolumn{2}{|c|}{ Yönetimde Görev Alma } & \multirow{2}{*}{$\begin{array}{c}\text { Toplam } \\
\text { Total }\end{array}$} \\
\hline & & Evet & Hayır & \\
\hline \multirow{4}{*}{$\begin{array}{l}\text { Eğitimi yok } \\
\text { No education }\end{array}$} & Sayı (Count) & 0 & 13 & 13 \\
\hline & Grup içindeki \% (Within Group) & 0.0 & 100.0 & 100.0 \\
\hline & Görev alma \% (Taking task) & 0.0 & 4.1 & 3.5 \\
\hline & Genel \% (General) & 0.0 & 3.5 & 3.5 \\
\hline \multirow{4}{*}{$\begin{array}{l}\text { İlköğretim } \\
\text { Primary School }\end{array}$} & Sayı (Count) & 32 & 212 & 244 \\
\hline & Grup içindeki \% (Within Group) & 13.1 & 86.9 & 100.0 \\
\hline & Görev alma \% (Taking task) & 62.7 & 66.7 & 66.1 \\
\hline & Genel \% (General) & 8.7 & 57.5 & 66.1 \\
\hline \multirow{4}{*}{$\begin{array}{l}\text { Lise } \\
\text { High school }\end{array}$} & Sayı (Count) & 16 & 72 & 88 \\
\hline & Grup içindeki \% (Within Group) & 18.2 & 81.8 & 100.0 \\
\hline & Görev alma \% (Taking task) & 31.4 & 22.6 & 23.8 \\
\hline & Genel \% (General) & 4.3 & 19.5 & 23.8 \\
\hline \multirow{4}{*}{$\begin{array}{l}\text { Yükseköğretim } \\
\text { Higher Education }\end{array}$} & Sayı (Count) & 3 & 21 & 24 \\
\hline & Grup içindeki \% (Within Group) & 12.5 & 87.5 & 100.0 \\
\hline & Görev alma \% (Taking task) & 5.9 & 6.6 & 6.5 \\
\hline & Genel \% (General) & 0.8 & 5.7 & 6.5 \\
\hline \multicolumn{2}{|l|}{ Genel toplam } & 51 & 318 & 369 \\
\hline
\end{tabular}

Çizelge 23. Yönetim kurullarında görev alma-eğitim ilişkisi Kuruskall-Wallis testi tablosu

Table 23. taking part in the management committee-education relationship Kruskal-Wallis test table

\begin{tabular}{|c|c|c|c|c|c|}
\hline Eğitim durumu (Education Status) & $\mathrm{N}$ & Sira Ort. (Row Average) & $\mathrm{SD}(D F)$ & $x^{2}$ & $\mathrm{p}$ \\
\hline Ĕgitimi yok (No education) & 13 & 210.50 & \multirow{5}{*}{3} & \multirow{5}{*}{3.617} & \multirow{5}{*}{0.306} \\
\hline İlköğretim (Primary school) & 244 & 186.30 & & & \\
\hline Lise (High school) & 88 & 176.95 & & & \\
\hline Yükseköğretim (Higher education) & 24 & 187.44 & & & \\
\hline Toplam (Total) & 369 & & & & \\
\hline
\end{tabular}

Çizelge 24. Yetiştiricilerin gelirlerine göre yönetim kurullarında görev alma durumu

Table 24. Taking part in the management committee according to the income of breeders

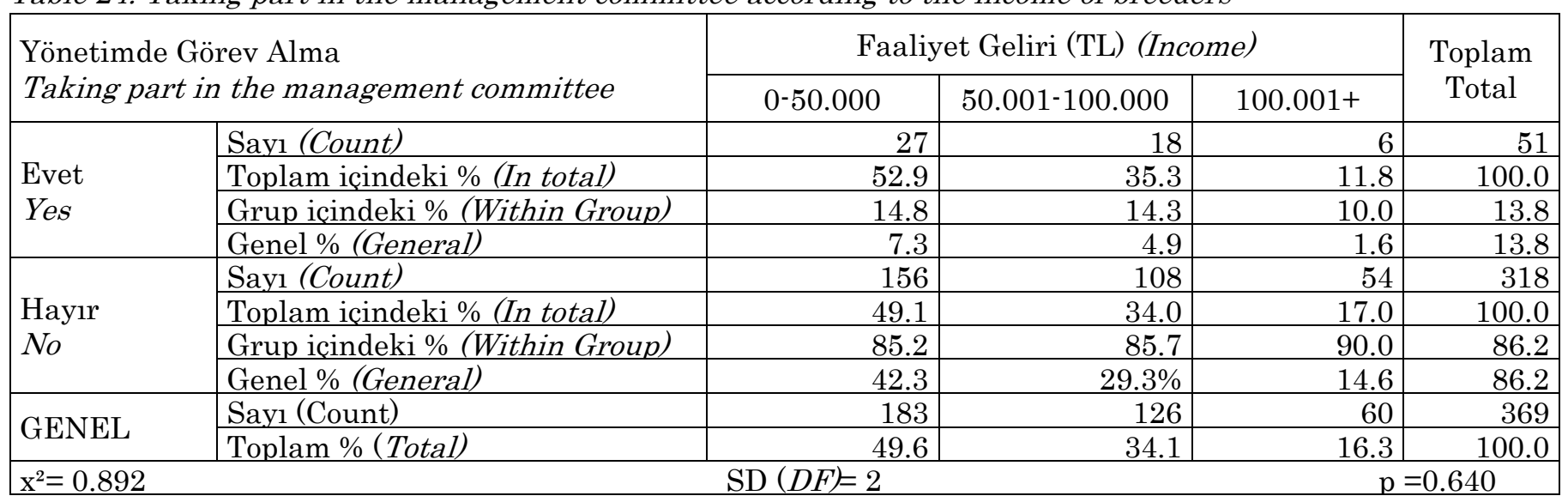

DSYB üyeleri tarafından dile getirilen sığır yetiştiricilerinin sorunları;

- Kesif yem, mazot, gübre ve veterinerlik hizmetleri başta olmak üzere girdilerin çok pahalı olması buna karşın başta süt olmak üzere ürünlerinin hak ettiği değeri bulamaması.

- Hayvancılık piyasasındaki istikrarsızlık, damızlık 
materyal bulma ve suni tohumlama hizmetlerinden etkin olarak yararlanamamak.

- Koruyucu sağlık hizmetlerinin düzensiz olması, aşılama çalışmalarına rağmen salgın ve bulaşıcı hastalıklarla mücadelede istenen sonuçlara ulaşlamaması, desteklemelerin yetersizliği ve birlikler aracılığı ile dağıtıldığı dönemlerde yetiştiricilerin eline tam olarak ulaşmaması.

- Yörede etkin ve yaygin pazarlama organizasyonlarının olmaması, birliklerin bu anlamda yeterince çaba sarf etmemesi. Ürünlerin çiftlik avlusundaki fiyatları ile marketlerin raflarındaki fiyatları arasındaki fark. Ayrıca birliklerin çiftçi örgütü olmasına karşın kar amacı güden şirketler gibi faaliyet göstermesi ve işletme sermayesi bulma konusunda zorluklar.

DKKYB üyelerinin dile getirdiği küçükbaş hayvan yetiştiricilerinin sorunları;

- Çoban bulunmaması, meralarin yetersiz ve kalitesiz olması ve farklı amaçlar için kullanıma açılması.

- Mevcut barınakların yeterli hava ve ışıktan yoksun olması, köy yerleşim alanları içerisinde bulunması.

- Mazot ve gübre gibi girdilerin yanı sıra veterinerlik hizmetlerinin pahalı olması.

- Desteklerin yetersiz olması, piyasalardaki istikrarsızlık,

- Koruyucu hayvan sağllğı hizmetlerinin yetersizliği ve salgın ve bulaşıcı hastalıklarla mücadelede yaşanan problemler.

- Yapağının herhangi bir ekonomik değerinin olmamasi.

Arı yetiştiricilerinin dile getirdikleri problemler;

- AYB üyelerinin hemen tamamı ürettikleri balın kalitesini ispat edememek, analiz ücretlerinin yüksekliği, sahte bal probleminin çözülememesi.

- Birliklerin pazarlama organizasyonu yapmaması, kaliteli ve güvenli temel petek ve döllenmiş ana arı başta olmak üzere girdi temini

- Pestisitlerin bilinçsiz ve fazla miktarda kullanımının kolonileri ve bal üretimini olumsuz etkilemesi, çevre kirliliğine sebep olması.

- Hem gezginci hem de sabit arıcıllk yapan yetiştiricilerin konaklama sorunu, kapasite hesaplamada yanlışlar, konaklama bölgelerinde altyapı eksikliği ve rant olarak görülmesi,

- Devlet desteklerinin ve arı hastalıkları ile mücadelenin yetersiz olması.

\section{SONUÇ ve ÖNERILER}

Güçlü bir üretici örgütlenmesi, tarım sektörünün diğer bileşenleri üzerinde de olumlu etkiye sahip olabilecektir. Tarımsal sanayinin motive edilmesi, araştırma geliştirme faaliyetlerinin üreticilerin talepleri ile ve üretimle doğrudan bağlantılı olarak gelişmesi ve en önemlisi tüketiciler açısında güvenilir gıdaya erişim bu olumlu etkilerden birkaçı olabilir. Örgütsüzlüğün getirdiği yalnız kalma duygusu, korumasız ve dayanışmadan yoksun üreticiler açısından güçlü bir örgütlülüğün birçok sosyal sorunun giderilmesi hiç olmazsa azaltılmasına da katkıda bulunacağı kaçınılmazdır.

Farklı birliklerin üyeleri arasında eğitim seviyeleri açısından ciddi farklılıklar göze çarpmaktadır. Birlikler üzerinden yetiştiriciler için hazırlanacak tüm proje, eğitim ve yayım programları vb. faaliyetler birlik üyelerinin eğitim düzeyleri göz önüne alınarak dizayn edilmeli ve yetiştiriciler açısından anlaşılır olmalıdir.

Kırsal alanda gençlerin istihdamına katkı sağlayacak ve genç yetiştiricileri hayvancılık sektöründe tutacak düzenlemelere ihtiyaç vardır. İş yükünün ağır olduğu kırsal alanda gençlerin evlilik konusunda zorluk yaşadıkları gözlenmektedir. Evli gençlerin bir kısmının ise okul çağına gelen çocuklarına daha iyi bir eğitim sağlamak veya eğitim hayatlarında çocuklarının yanlarında olabilmek için hayvancılık faaliyetlerinden vazgeçerek şehir merkezlerine göç ettikleri bilinmektedir. Tüm bunlar göz önüne alındığında genç yetiştiricilerin hayvancılık faaliyetlerini sürdürebilmeleri çok daha geniş çapta bir planlama ve entegre bir yaklaşım ile ancak olasıdır.

Genel olarak yetiştiricilerin mesleki deneyimlerinin oldukça iyi olduğu söylenebilir. Yetiştiricilerin deneyimlerini paylaşabileceği ve aralarında mesleki dayanışmayı artırabilecekleri organizasyonların birlikler tarafindan hayata geçirilmesinin başta genç ve deneyimsiz üyeler olmak üzere tüm yetiştiriciler için olumlu sonuçlar doğuracağı söylenebilir. Dışarıdan bir yayımcı müdahalesi ile kabul edilmesi daha çok zaman alacak yeniliklerin, deneyim paylaşımı ile daha kısa sürede kabul edilebileceği düşünülmektedir. Yine yetiştiriciler için hazırlanacak yayım programları bu deneyimlerden yararlanılarak geliş̧irilmelidir.

Birlikler tarafindan bir pazarlama organizasyonu yapıldığında üyelerin ilgi gösterdiği söylenebilir. Birliklerin, yetiştiricilerden ürünleri sadece toplama ve pazarlama değil, katma değer yaratacak süreçleri hayata geçirmeleri gerekmektedir. Çeşitli hibe, eş finansman kaynakları hem araştırma bölgesi için hem de tüm iller için erişilebilir durumdadır. Birlikler bu programlardan yararlanma açısından kapasitelerini artırmalı ve çaba sarf etmelidir.

Çiftçi örgütleri, üye olabilecek hedef kitleye ulaşmak için yapacakları çalışmalarda faaliyet alanının özelliğine uygun programlar ortaya koymalıdır. Bu tür çalışmalar yaygın üretim tekniğine ve iş yükünün azaldığı dönemlere göre hayata geçirilmelidir.

Çevresinden bilgi edinen yetiştiricinin doğru bilgiye ulaşması konusunda problemler olabilmektedir. Yetiştiricilerin temas kurduğu diğer yetiştiricilerin 
bakış açısıyla çiftçi örgütleri hakkında ilk bilgilerini edinmelerinin olumsuz sonuçlar doğurması olasıdır. Birliklerde görevli tarım danışmanlarının ve il/ilçe müdürlüklerinin örgütlenmenin önemi ve birliklerin varlık amaçları ile ilgili doğru ve eksiksiz bilgiyi yetiştiricilere ulaştırmak için daha fazla inisiyatif almaları gerekmektedir.

Çiftçi örgütleri açısından esas olan kamudan tamamen bağımsız ve kendi ayakları üzerinde durabilen, sürdürülebilir yapılar olmalarıdır. Ancak özellikle Türkiye'de ve benzer durumdaki, çiftçi örgütlenmesinin zayıf olduğu gelişmekte olan ülkelerde yetiştiricilerin çiftçi örgütlerine üye olmalarını özendirecek politika araçlarının kullanılması doğrudur. Bunun yanı sıra çiftçi örgütlerinin kurucularının ve tarım danışmanlarının üreticilere ulaşma ve ikna etme süreçlerinde daha aktif rol almaları gerekmektedir.

Yetiştiricilerin, üye oldukları birliklerin geleceğini planlayan ve yönetecek olan kurulun seçildiği süreçlere dahil olmaları son derece önemlidir. Tüm yetiştiricilerin bu süreçlere dahil olabileceği yollar oluşturulmalıdır. Bu çalışmada olduğu gibi faaliyet alanı son derece geniş olan birlikler/çiftçi örgütleri başta olmak üzere, üyelerin tamamına genel kurul kararın, yerini ve tarihini bildirmek zorunlu hale getirilmelidir. Dolayısıyla genel kurulların zamanı belirlenirken faaliyet alanına göre görece daha az iş yükünün olduğu dönemlerin dikkate alınması genel kurullara katılımı olumlu yönde etkileyecektir.

Demokratik örgütlerde üyelerin çoğunluğunun yönetime aktif olarak katılması beklenmektedir. Daha fazla üyenin yönetim kurullarına gönüllü katılımı için teşvik edici önlemler alınmalıdır.

Birlik tarafından sağlanan herhangi bir eğitim programına katılmıs olmak birlik ile bir temas anlamına gelmektedir ve üyenin birliğini tanıması açısından oldukça önemlidir. Birlikler üyeleri ile teması artıracak çalışmaları organize etmeli ve kendilerini öncelikle üyelere anlatarak işe koyulmalıdır.

Birlikler, üyeleri için en önemli yayım organizasyonlarından biri olmak durumundadir. Çalıştıkları alanı, üyeleri ve yöreyi çok iyi tanıması beklenen birliklerin/çiftçi örgütlerinin bu özellikleri ile öne çıkmaları beklenirken üyeler için eğitim ve yayım programlarında geri kalmış olmaları çok ciddi bir eksikliktir. Kendi faaliyet alanlarında yapılan bilimsel çalışmaların, araştırmaların ve üyeleri ilgilendiren her türlü politik ve ekonomik kararın üyelere ulaştırılması için birliklerin daha fazla sorumluluk almaları gerekmektedir.

Birlikler üyelerin düşüncelerini ve taleplerini dönem dönem küçük çaplı anket çalışmaları ile belirlemeli ve çalışma programlarında bu taleplere yer vermelidir.

Birlikler, yatırım konusunda üyelerin önlerini açacak çalışmaları hayata geçirmelidir. Gerek pazar araştırmaları ile gerekse teknik olarak yetiştiricileri rahatlatacak ve doğru karar vermelerini sağlayacak çalışmalar yaparak üyelerine sunmalıdır.

Özellikle eğitimi olmayan üyelerin genel kurullara daha az katılım gösterdiği görülmektedir. Daha az eğitimli üyelerinde kendilerini ifade edebilmeleri ve birliklerin yönetim mekanizmalarına katılabilmeleri için gerekli önlemler alınmalıdır. Tüm kesimlerin mesleki bilgi birikiminden yararlanılmalı, daha katılımcı ve yenilikçi yöntemler hayata geçirilmelidir. Bunun için resmi organlarda görev almasalar bile düzenli olarak üyelerin görüşlerini paylaşabilecekleri ve önerilerini sunacakları toplantılar organize edilmelidir. Aynı durum üye yetiştiricilerin gelir grupları için de söz konusudur ve bu alanda da gerekli önlemler alınmalıdır.

Girdi temin etme çabasının, diğer tüm ekonomik durumlardan bağımsız olarak girdi fiyatlarında küçük de olsa bir düşüş oluşturacağı açıktır. Damızlık materyal bulma konusunda üyelerin yaşadığı problemleri çözebilmek adına en azından birlikler kendi içerisinde bir organizasyona gitmeli ve ihtiyaç sahipleri ile satıcıları buluşturmalıdır. Birlikler katma değer yaratacak faaliyetlere yönelerek çiftlik fiyatı ile raf fiyatı arasındaki farkın üreticinin hesabına yazılabilmesi için gerekli önlemleri almalıdır.

Koyun yetiştiricileri arasında dile getirilen en büyük problemlerden birisi çoban bulunamamasıdır. Çobanlara yönelik kamunun dönem dönem bazı destekleri olmuş ancak dönemsel desteklemeler kalıcı bir sonuç yaratmamıştır. Bunlardan en önemlisi çobanlar için uygulanan sigorta desteğidir. $\mathrm{Bu}$ desteğin sürekli hale getirilmesi, aylık ücretlerin bir kısmının devlet tarafından karşılanması gibi kapsamı genişletilmiş desteklemeler sorunun çözümüne katkı sunacaktır.

Mera alanlarının amaç dışı kullanıma açılması, yetersiz ve kalitesiz olması en çok koyun yetiştiricilerini olumsuz etkilemektedir. Mevcut mera ıslah projeleri beklenilen sonucu vermemiştir. Mera ıslah projelerinin yeni bir anlayışla ele alınması gerekmektedir. Yetiştiricilerin sürülerini meralar için kritik dönemlerde meralardan uzak tutabilmesi için ilave kaba yem desteklemelerinin yapılması meralar üzerindeki baskıyı azaltacak ve meraların toparlanmasına katkı sağlayacaktır. Mera kapasitelerinin hesaplamaları daha özenli yapılmalıdır.

Koruyucu hayvan sağllğ hizmetleri ve programl aşılamaların takibi yapılmalı ve bu hizmetlerin zamanında yerine getirilmesi sağlanmalıdır. Birlikler bu konularda ilgili kamu kurumları ile işbirliği içinde olmalıdir.

Bal konusunda gelişmiş analizleri daha uygun ücretlerle yapabilecek laboratuvarların kurulumu 
veya üyelerin ballarının analizinin daha uygun koşullarda anlaşmalı laboratuvarlar aracılığı ile yaptırabilmeleri için birlikler inisiyatif alabilirler.

Değişen iklim koşullarına göre bölgelerin koloni kapasiteleri yeniden hesaplanmalıdır. Birlikler bu konuda daha bilimsel ve uyarıcı faaliyetlerde bulunmalı, ilgili kurumlar ile işbirliği içinde olmalıdır. Bitkisel üretim yapılan alanlarda bitki zararlıları ile mücadelede doğa dostu yöntemler denenmelidir. Zorunlu olarak pestisit kullanımı gerekli ise kontrollü şekilde ve yöredeki arı yetiştiricileri ile iletişim halinde kullanımı sağlanmalıdır.

\section{Çıkar Çatışması Beyanı}

Makale yazarları aralarında herhangi bir çıkar çatışması olmadığını beyan ederler.

\section{Araştırmacıların Katkı Oranı Beyan Özeti}

Yazarlar makaleye eşit oranda katkı sağlamış olduklarını beyan ederler.

\section{KAYNAKLAR}

Akkurt M, Köknaroğlu H 2016. Isparta İli Damızlık Sığır Yetiştiricileri Birliğine Üye Olan ve Olmayan İşletmelerin Performanslarının Karşılaştırılması ve Üreticilerin Damızlık Sığır Yetiştiricileri Birliği İle İlişkilerinin İncelenmesi. Süleyman Demirel Üniversitesi Ziraat Fakültesi Derg 11 (2): 79-90.

Aydoğan M, Yulafçı A 2014. Samsun İlindeki Tarımsal Üretici Örgütlerinin Yapısal Sorunları ve Çözüm Önerileri. 11. Tarım Ekonomisi Kongresi 3-5 Eylül 2014, Samsun

Bilginturan S, Ayhan V 2009. Burdur İli Damızlık Koyun ve Keçi Yetiştiriciler Birliği Üyesi Koyunculuk İşletmelerinin Yapısal Özellikleri ve Sorunları Üzerine Bir Araştırma. Hayvansal Üretim Derg 50 (1): 1-8.

Çetin H 2013. Kamu Ekonomisi Yönünden Türkiye'de Kırsal Kalkınma Sürecinde Kooperatifçiliğin Rolü Tariş Zeytin ve Zeytinyağı Birliği Örneği. Dokuz Eylül Üniversitesi Sosyal Bilimler Enstitüsü Maliye Anabilim Dalı, Doktora Tezi, 255 sy.
Falkowski J, Ciaian P 2016. Factors Supporting the Development of Producer Organizations and their Impacts in the Light of Ongoing Changes in Food Supply Chains. http://publications.jrc.ec.europa.eu/ repository/handle/JRC101617.

Göktolga ZG 2015. İktisadi ve İdari Bilimler için İstatistik. Seçkin Yayıncılık, Ankara, 376 sy.

İnan İH, Gülçubuk B, Ertuğrul C, Kantürer E, Baran EA, Dilmen Ö 2000. Türkiye'de Tarımda Kırsal Kesim Örgütlenmesi. http://www.zmo.org.tr/ resimler/ekler/00c563bfd2c48c1_ek.pdf?tipi=14\&su be.

Karaturhan B, Şevi T, Yıldız Ö 2014. Yetiştirici Birliklerinin Tarımsal Kalkınmaya Etkileri Üzerine Bir Araştırma: Edirne Damızlık Sı̆̆ır Yetiştiricileri Birliği Örnek Olayı. Ege Üniversitesi Ziraat Fakültesi Derg 51 (2): 175-184.

Murat H 2011. Eğe ve Orta Anadolu Bölgesi Damızlık Sığır Yetiştiricileri Birliğine Bağlı Süt Sığırcılık İşletmelerinin Ekonomik Analizi. Ankara Üniversitesi Sağlık Bilimleri Enstitüsü Hayvan Sağlığı Ekonomisi ve İşletmeciliği Anabilim Dalı, Doktora Tezi, 241 sy.

Önal R, Özder M 2008. Edirne İli Damızlık Sığır Yetiştiricileri Birliğine Üye İşletmelerin Yapısal Özellikleri. Tekirdağ Ziraat Fak Der Derg 5 (2): 197-203.

Sağlam U 2013. Uşak İlinde Tarımsal Üretici Örgütlenmesi ve Yapısal Sorunlar. Namık Kemal Üniversitesi Fen Bilimleri Enstitüsü Tarım Ekonomisi Anabilim Dalı, Doktora Tezi, 199 sy.

Sarı MM 2016. Tarım İşletmelerinin Örgütlenme Durumu ve Buna Etki Eden Faktörlerin Belirlenmesi: Erzurum ili Örneği. Atatürk Üniversitesi Fen Bilimleri Enstitüsü Tarım Ekonomisi Anabilim Dalı, Yüksek Lisans Tezi, 58 sy.

Terin M, Ateş Ç H 2010. Çiftçilerin Örgütlenme Düzeyi ve Örgütlerden Beklentileri Üzerine Bir Araştırma: Van İli Örneği. Ege Üniversitesi Ziraat Fakültesi Derg 47 (3): 265-274.

Yamane T 2006. Temel Örnekleme Yöntemleri. Nobel Yayınları, Ankara, 509 sy. 